\title{
Dynamic development of the thin-skinned thrust faulting
}

The dynamic development of the thin-skinned thrust faulting in the Rubjerg Knude Glaciotectonic Complex is presented as a sequence of restoration stages. Thus, the progressive deformation of thin-skinned thrust faulting and related syntectonic depositional developments are illustrated in sequentially restored crosssections beginning with the proximal Moserende Section and concluding with the Ulstrup Section in the most distal part of the thrust-fault complex. The basis of each restoration sequence is the balanced profile (Plate 2A), and the end stage is identical with the thrustfault cross-section (Plate 2B), including the interpretation of the unexposed ramps and flats in the subsurface. The mostproximal sections, the Mårup Kirke and the Ribjerg Sections were interpreted individually in the preceding chapters, and are not included here.

In a summary scheme (see Fig. 123), it is concluded that the dynamic development was a process of continuous progressive deformation. Thus, although the following description is concentrated on the individual sections, it should be kept in mind that there is overlap between sections, and that the whole system was mobile. Thus a displacement of $5 \mathrm{~m}$ on one thrust might be followed by $10 \mathrm{~m}$ on a more proximal thrust and $7 \mathrm{~m}$ on a more distal thrust depending on the local conditions. This is the reason why a number of displacements appear to be out-of-sequence, but within limits that respect the lowest décollement level, and that displacements along the most distal, leading-edge thrusts were the last to be activated. It is therefore also evident that displacement along a leading-edge ramp may correspond to a translation along a flat in a proximal section.

\section{Moserende Section}

The thrust-fault development in the Moserende Section is regarded as normal progressive piggyback thrusting from the proximal towards the distal part. The MR12 thrust sheet was probably the first to be thrust onto the relatively thinner piggyback basin on the back of MR11 after a c. 10 m thickness of Rubjerg Knude Formation sediments had been deposited. This is included in the first stage of the sequential restoration (Fig. 112, stage 1). A total of eight stages have been differentiated, of which stages 1-6 are illustrat- ed in Fig. 112. The stage preceding the deformation is shown in Plate $2 \mathrm{~A}$, and the final stage terminating the deformation is reconstructed in Plate 2B.

Moserende stage 1. The initial thrusting started with $40 \mathrm{~m}$ displacement of MR12 over the back of what was to become MR11. This thrusting was rooted down to the $20 \mathrm{~m}$ intermediate décollement level. During accumulation of a $20 \mathrm{~m}$ thick succession of sediments in the piggyback basins above the MR13 and MR12 sheets, the thrusting progressed with ramping of MR11 over the Rubjerg Knude Formation on top of what was to become MR10. This thrusting involved ramping and translation of the lower segments of MR13MR11 from the $30 \mathrm{~m}$ flat level onto the $20 \mathrm{~m}$ flat level. The trailing-end segments of the Moserende Section were contemporaneously over-thrust by MK01, the frontal thrust of the Mårup Kirke Section, which is rooted in the $40 \mathrm{~m}$ décollement level. The accumulated displacement of thrusting of MR13, MR12 and MR11 is estimated at about $150 \mathrm{~m}$.

Moserende stage 2. Thrusting of MR09 initiated this stage. The MR09 thrusting ramped up from the $40 \mathrm{~m}$ décollement level, and a single duplex formed during stacking of the lower MR09 thrust segment. The MR09 sheet was displaced c. $40 \mathrm{~m}$ over the MR08 piggyback basin. Contemporaneously, MR10 was thrusted over MR09 and the MR10 hanging-wall flat extended from the top flat level down to the $40 \mathrm{~m}$ décollement level. The MR13-MR11 thrust sheets were then passively translated on the trailing lower segment of MR10.

Moserende stage 3. Initial imbrication of the MR08MR05 thrust sheets resulted in an accumulated displacement of c. $200 \mathrm{~m}$. The ramping was rooted in the $40 \mathrm{~m}$ décollement level along which the main translation of the trailing-end thrust sheets of the Moserende Section took place. The thrusting involved a complex relationship between MR07 and MR06 that may be interpreted as a connecting splay duplex (Mitra \& Sussman 1997). Above the L/R-unconformity, the deposits of the Rubjerg Knude Formation probably reached a thickness of $20 \mathrm{~m}$.

Moserende stage 4 . The frontal part of the section was activated by c. $40 \mathrm{~m}$ translation of MR1 along the $30 \mathrm{~m}$ 
décollement level over the lowermost trailing-end segments in the Stortorn Section. MR02 and MR03 followed this translation, whereas MR04 ramped up one level from the $40 \mathrm{~m}$ décollement level to the $30 \mathrm{~m}$ flat level that resulted in the initial ramping of MR04 up over the Rubjerg Knude Formation on the back of MR03. The continued displacement consequently reorientated thrust sheets MR05-MR07 into more steeply dipping orientations. The trailing-end thrust sheets from MR08 and northwards were translated passively during this displacement.

Moserende stage 5. The frontal displacement of MR01 continued along the $20 \mathrm{~m}$ flat level over the trailingend segment of the Stortom Section. MR02 ramped up along the footwall ramp at the trailing end of MR01 during a fault-bend rotation, which also included the lower segment of MR01u. A vertical thrust separation of c. $10 \mathrm{~m}$ brought MR02 up along the northern termination of the MR01 piggyback basin. During the passage of two intermediate ramps, an irregular anticline formed on the back of MR02 that had significant implications for the synsedimentary structures formed in the MR02 piggyback basin (see description of the Moserende Section, above).

During MR04 thrusting, MR03 was imbricated along the upper $10 \mathrm{~m}$ flat level and the MR03b and MR03c thrust segments started to break through the piggyback basin. From the rear, MR04 was pushed by MR05 which had to pass up over the fault-bend-folded segment MR04u. Together with MR06 and MR07, the MR05 thrust sheet moved up to the highest level indicated by the L/R-unconformity, situated c. $20 \mathrm{~m}$ above sea level on the back of MR06 and MR07, and their thrust faults were steepened into a nearly vertical position.

Moserende stage 6. In the frontal part of the Moserende Section, MR01 picked up a lower segment and thrust up to the $20 \mathrm{~m}$ flat level, which consequently also elevated the piggyback basin up into its present high level. The trailing-end ramp of MR01 formed the footwall ramp for the MR02 thrusting, which resulted in a fault bend of MR02 as well as MR03. This was followed by the final displacement of $18 \mathrm{~m}$ along the leading MR03 thrust. Minor adjustments and re-orientation of MR04-MR07 followed the ramping of MR03, and the trailing-end thrust sheets MR08-MR13 were passively displaced by translation along the $40 \mathrm{~m}$ décollement level.

Moserende stage 7. During this stage, a complex duplex was formed by thrusting of the frontal lower seg- ments, which also including the trailing-end segments of the Stortorn Section.

Moserende stage 8. The final displacement along the leading thrust-fault ramp in the Moserende Section progressed up along the Stortom trailing-end footwall ramp. Moreover, the fault-bend folding due to thrusting in the Stortorn Section brought the thrust sheets into their present steeply dipping orientation.

\section{Moserende Section: Summary data \\ Balanced length $\left(\mathrm{L}_{0}\right)$ : $\quad 1120 \mathrm{~m}$ Cross-section length $\left(\mathrm{L}_{1}\right): \quad 650 \mathrm{~m}$ Shortening $(\Delta \mathrm{L})$ : $\quad 470 \mathrm{~m}$ Compression: $\quad 40.2 \%$}

\section{Stortorn Section}

The most important development in the Stortorn Section was the change from the lowermost $40 \mathrm{~m}$ décollement level to the $30 \mathrm{~m}$ décollement level. The ramp, or progressive development of lower ramps, which marked the change, is here referred to as the Stortorn lower segment footwall ramp, and was located somewhere near the thrust between ST04 and ST03. Thus, the ST03-ST01 thrust sheets had their lower décollement level at $30 \mathrm{~m}$, whereas the thrust faults related to ST04-ST10 were rooted in the $40 \mathrm{~m}$ décollement level.

Formation of a duplex complex comprising the lowermost thrust segments exposed the Stortorn Formation, the oldest strata involved in the thrusting. In the frontal part of the section, a complex stacking of lower segments, remaining in the subsurface from displacement in the Grønne Rende Section, resulted in duplex formation that elevated ST01-ST03 about $30 \mathrm{~m}$ above the reference level. Due to arguments presented later (see Grønne Rende Section) the duplex stacking had to have been contemporaneous with the shortening of the Grønne Rende Section. In the Stortorn Section, seven stages have been differentiated of which stages 1-5 are illustrated in Fig. 113.

Stortorn stage 1. This stage is a direct continuation of the displacement in Moserende stage 4. In the Stortorn Section, deformation was initiated by imbrication of ST07, ST09 and ST10 with an accumulated displacement of about $50 \mathrm{~m}$. This resulted in a ramping 


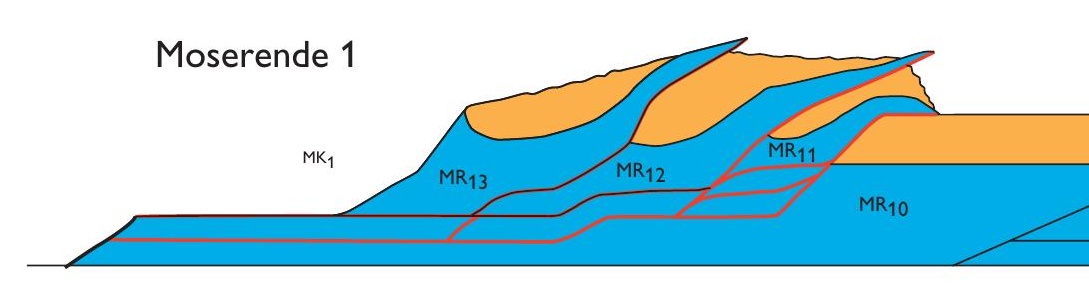

\section{Moserende 2}

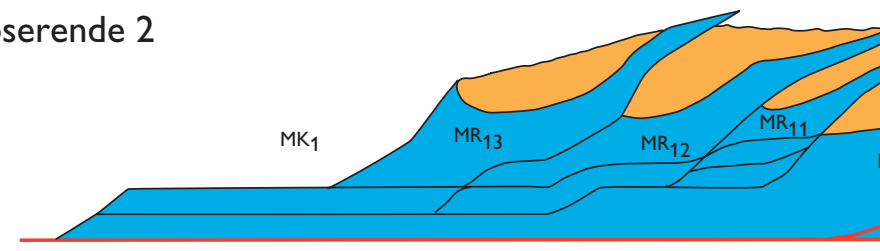

Moserende 3

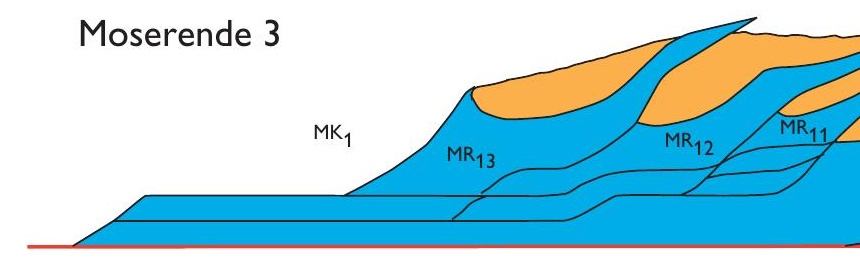

Fig. 112. Dynamic model of progressive deformation in the Moserende Section illustrated in

\section{Moserende 4}

six sequential restoration cross-sections. The six stages demonstrate steps in the development between the balanced cross-section and the structural cross-section (Plate 2); thus the starting and final positions are not shown. The red lines indicate the active displacement surfaces in each deformation stage. The basic décollement surface is the $40 \mathrm{~m}$ flat level. From this, the flat levels rise by $10 \mathrm{~m}$ onto the reference level (L/Runconformity) defined as the 0-level. Note (1) that the final two stages $(7,8)$ discussed in the text are not illustrated, and (2) that the thrustsheet terminology in Figs 112-122 is simplified (i.e. $\mathrm{MR}_{3}$ on Fig. 112 is equivalent to MR03 in the text).

\section{Moserende 5}
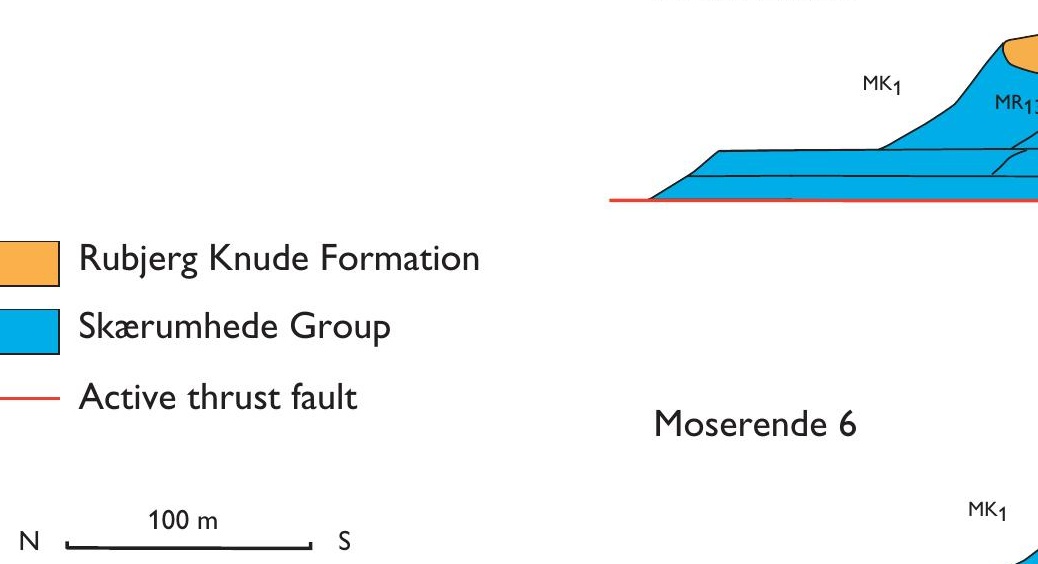

Moserende 6

\section{Rubjerg Knude Formation}

Skærumhede Group

Active thrust fault

$\mathrm{MK}_{1}$ 

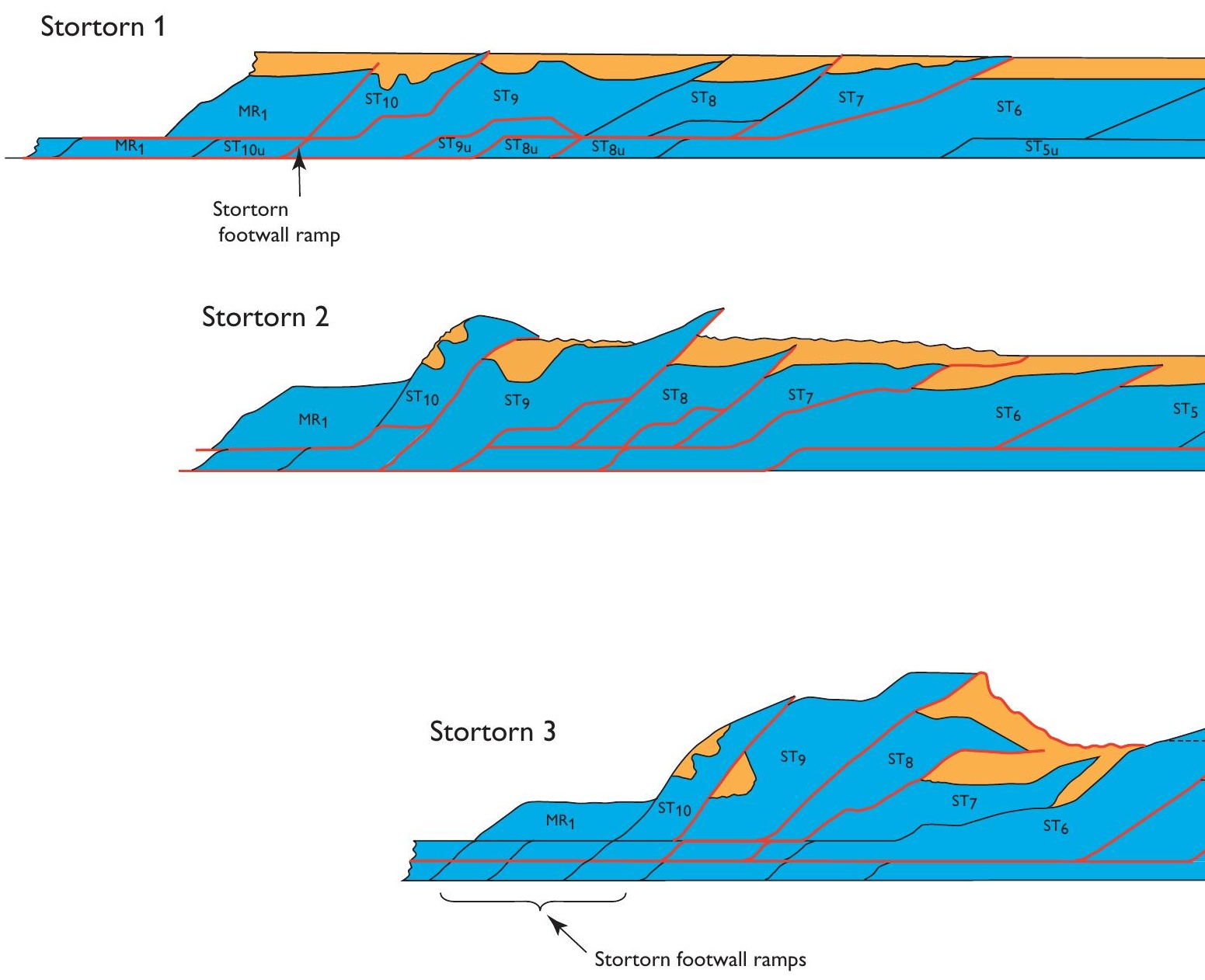

Fig. 113. Dynamic model of progressive deformation in the Stortorn Section illustrated

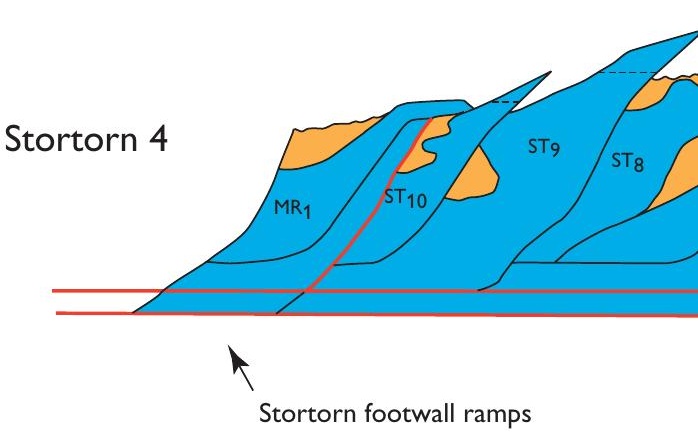
in five sequential restoration cross-sections. The cross-sections demonstrate steps in the development between the balanced crosssection and the structural cross-section (Plate 2); thus the starting and final positions are not shown. The red lines indicate the active displacement surfaces in each deformation stage. Note that the duplex segments $G_{u}$ refer to elements that had to be deformed contemporaneously with the shortening taking place in the Grønne Rende Section; duplex segments ST refer to horse/splint segments. The final two stages $(6,7)$ discussed in the text are

Rubjerg Knude Formation

Skærumhede Group

\section{Active thrust fault}

N $100 \mathrm{~m}$ $\mathrm{S}$

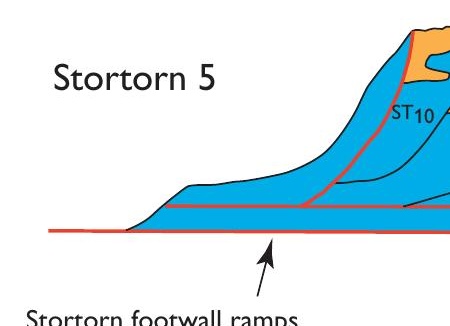

Stortorn footwall ramps 
up of ST10 from décollement level $40 \mathrm{~m}$ to flat level $30 \mathrm{~m}$, along which the translation displacement took place. Most of the ST09 thrust sheet was also ramped up by the formation of a lower duplex structure. Both ST10 and ST09 were affected by fault-bend folding, which created a majordistortion of the L/R-unconformity surface in the uppermost part of the thrust sheets.

Stortorn stage 2. During an accumulated displacement of about $200 \mathrm{~m}$ related to the ST10 and ST09 thrusts, ramping progressed with development of the first imbrications of ST08 and ST06. Due to ramping from the lowest décollement level to the $30 \mathrm{~m}$ flat level in the trailing end of ST06, a fault bend affected the ST07ST10 thrust sheets that were translated piggyback on the ST06 thrust sheet. This contributed to the steepening up of the ST07-ST10 thrust structures.

In the frontal part of the section, the imbricate thrusting was initiated at ST01-ST03. Accumulation of sediments referred to the Rubjerg Knude Formation reached a maximum thickness of about $20 \mathrm{~m}$, notably in the synformal troughs of ST03 and ST09 that formed during the progress over the ramps below.

Stortorn stage 3. At this stage, ST05 was thrust about $40 \mathrm{~m}$ up over the footwall ramp on the back of ST04. The ST05 thrust was rooted in the $30 \mathrm{~m}$ flat level, and during a passage of a lower ramp from flat level $30 \mathrm{~m}$ to $20 \mathrm{~m}$, the initial fault-bend-fold resulted in undulation of the L/R-unconformity at the top of the ST05 thrust sheet. The ST06 thrust sheet progressed over the footwall flat of ST05, and both thrust faults were rooted down to the $30 \mathrm{~m}$ flat level along which the main translation of the sheets emplaced piggyback on ST06 took place. The ST08 thrust sheet was finally displaced along the upper flat at the top of the ST07 piggyback basin. Consequently, most of the $20 \mathrm{~m}$ thick succession in this piggyback basin was preserved and indicates the maximum level of sediment accumulation in the Rubjerg Knude Formation during stage 3. Thrusting of the ST08 sheet along the footwall ramp on the back of ST07 resulted in a further steepening of ST09 and ST10, while the frontal elevated parts of the ST08-ST09 thrust sheets became subject to erosion.

The trailing-end lower segments of ST10-ST07 were over-thrust by the frontal parts of MR01 and MR02, corresponding to stage 7 in the Moserende Section. The accumulated displacement in Stortorn stage 3 was of the order of $320 \mathrm{~m}$.

Stortorn stage 4. During this stage, the ST04 thrust sheet was thrust $40 \mathrm{~m}$ over the piggyback basin of ST03, and ST05 was thrust about $70 \mathrm{~m}$ over the upper flat on top of the piggyback basin of ST04. During this relatively large displacement of ST05, two lower duplex segments were picked up from the lower 40 $\mathrm{m}$ décollement level. After ramping over the Stortorn lower ramp, the duplex segments participated in the thrusting up along the footwall ramp on the back of ST04.

The lower trailing-end segments of the Stortorn Section were finally thrust up along the steep footwall ramp on the back of ST10 and subsequently the frontal parts of the Moserende Section were brought into their present upright orientation. Erosion and redeposition affected the piggyback basins on ST05 and ST08, whereas thrusting over ST07 and ST04 sealed these piggyback basins. The accumulated displacement reached about $410 \mathrm{~m}$.

Stortorn stage 5. A substantial displacement, in the order of $80 \mathrm{~m}$, took place along the leading thrust in the Stortorn Section at this relatively late stage of development of the structures at Stortorn. However, this is only a small amount of the accumulated displacement (c. $500 \mathrm{~m}$ ) which is of the same order of magnitude as that taken up by the duplex stacking of the lower trailing-end segments of the Rubjerg Knude Fyr and Grønne Rende Sections. The ramping and thrusting of ST01-ST04 over this duplex structure explains the high elevation of the L/R-unconformity and overlying piggyback basins in the frontal part of the Stortorn Section. The formation of the duplex stack comprising the lower duplex segments annotated GRu in Fig. 113 would have taken place only after the imbricate thrusting in the Grønne Rende Section developed (see below). The combination of displacement at the leading edge in one section and stacking of lower duplex segments in another, indicates a continuous progressive thrust-fault evolution.

During the propagation of ST05, the trailing end of ST04 was involved in a duplex formation that resulted in fault-bend folding of the earlier formed ST05 lower duplex at the Stortorn lower ramp. The piggyback basin on the back of the ST05 thrust sheet was deformed into a north-verging syncline due to steepening. A similar re-orientation is seen in the thrustisolated piggyback basins in ST10 and ST09.

A marked diapirism and remobilisation of mud in the ST01-ST03, ST05-ST07 and ST09 thrust sheets suggests that the diapirism was related to the intensity of ramping, especially when the ramping involved the 

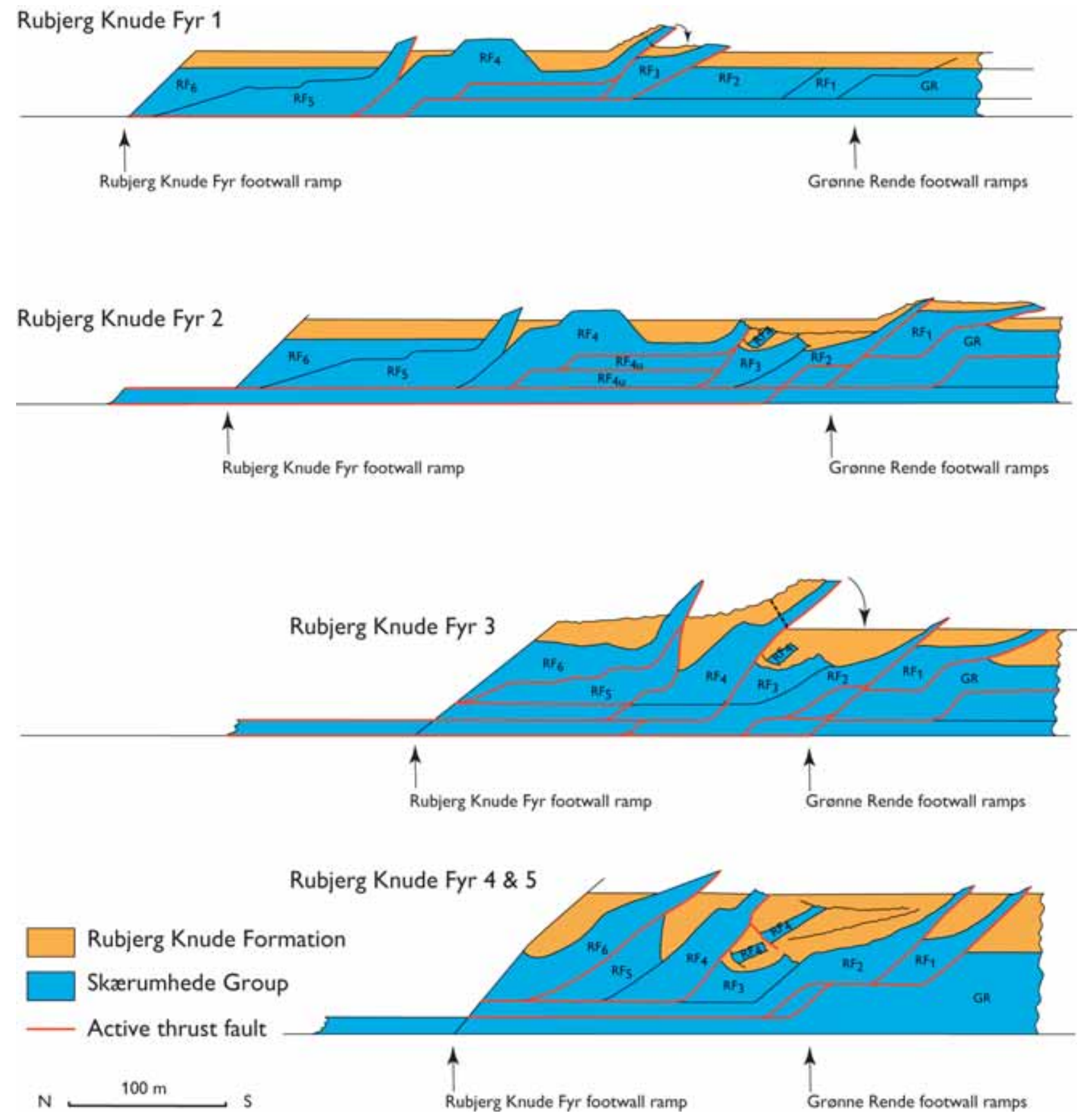

Fig. 114. Dynamic model of progressive deformation in the Rubjerg Knude Fyr Section illustrated in four sequential restoration cross-sections. The cross-sections demonstrate five stages in the development between the balanced cross-section and the structural cross-section (Plate 2). The red lines indicate the active displacement surfaces in each deformation stage. Note that the tip of the RF04 thrust sheet was displaced by normal faulting during syntectonic deposition in the RF03/RF04 piggyback basin.

lower level segments and fault-bend folding of these segments.

Stortorn stage 6 . The final ramping of lower segments from décollement level $40 \mathrm{~m}$ to flat level $30 \mathrm{~m}$ at the base of ST05 terminated the translation along the lowermost $40 \mathrm{~m}$ décollement level. For the sections fur- ther south, the lower décollement level was situated at the $30 \mathrm{~m}$ level. In the frontal part of the section, continued minor compression steepened the thrust structures, and the tips of ST02 and ST03 were eroded and deposited in the piggyback basin of ST01.

Stortorn stage 7. The structural complex, including the 
ST01 thrust sheet and the underlying duplex structure, became fault-bend-folded during the thrust propagation related to the progressive deformation in the Rubjerg Knude Fyr Section.

\section{Stortorn Section: Summary data}

$\begin{array}{lr}\text { Balanced length }\left(\mathrm{L}_{0}\right): & 1125 \mathrm{~m} \\ \text { Cross-section length }\left(\mathrm{L}_{1}\right): & 570 \mathrm{~m} \\ \text { Shortening }(\Delta \mathrm{L}): & 555 \mathrm{~m} \\ \text { Compression: } & 49.3 \%\end{array}$

\section{Rubjerg Knude Fyr Section}

The Rubjerg Knude Fyr Section roots into the $30 \mathrm{~m}$ décollement level. The most striking features developed in the Rubjerg Knude Fyr Section are the large olistoliths in the piggyback basin that were derived from the collapse and gravity gliding of a projecting segment of ST04. Five stages in dynamic development have been distinguished, which are illustrated by four cross-sections in Fig. 114.

Rubjerg Knude Fyr stage 1. During sedimentation of the first $10 \mathrm{~m}$ of sand of the Rubjerg Knude Formation, the RF05, RF04 and RF03 thrust sheets were thrust up along their footwall ramps. RF04 was displaced 90 $\mathrm{m}$ along the upper flat level $(10 \mathrm{~m}$ level) before the frontal part propagated up along the upper ramp. With a displacement of about $30 \mathrm{~m}$, this brought the nose of the RF04 thrust sheet up into the open air, above the sedimentation level of the Rubjerg Knude Formation. The displacementon theo ther two thrustsamounted to c. $20 \mathrm{~m}$, implying an accumulated displacement of $70 \mathrm{~m}$.

Rubjerg Knude Fyr stage 2. The exposed nose of the RF04 thrust sheet slumped down along a normal fault into the piggyback basin of RF03. At the same time, the frontal nose of RF03 was eroded away and sedimentation of the Rubjerg Knude Formation onlapped and covered these features. At the leading edge of the section, thrusting was initiated that brought RF01 and RF02 up over what was to become the trailingend segments of the Grønne Rende Section.

Rubjerg Knude Fyr stage 3. The frontal imbrication of RF01 and RF02 progressed during sedimentation up to about $20 \mathrm{~m}$ above the main L/R-unconformity lev- el. The RF05-RF06 thrust sheet ramped up onto the intermediate flat above the trailing-end segment of $\mathrm{RF} 04$. The RF04 thrust sheet was displaced about 70 $\mathrm{m}$ up along the relatively steep footwall ramp at the trailing end of RF03. Due to the fault-bend folding of RF04, the RF05-RF06 hanging-wall ramp was rotated into a vertical position.

Rubjerg Knude Fyr stage 4. When the second 'drop' of the frontal part of thrust sheet RF04 took place, ac. 45 $\mathrm{m}$ long slab of the relatively thin thrust-sheet nose slumped down along a normal fault with a vertical separation of more than $10 \mathrm{~m}$. The 'drops' may be regarded as two break-back sequences of the RF04 thrust sheet (in the terminology used by Mitra \& Sussman 1997; see Figs 99, 100). Sediment accumulation continued in the piggyback basin to a thickness of more than $30 \mathrm{~m}$, including the 'dropped' noses of RF04. The final accumulation in the piggyback basin took place while the displacement in the Rubjerg Knude Fyr Section was concluded more than 500 m laterally to the south. The translation progressed along the 20 $\mathrm{m}$ flat level on top of what was to become the lower trailing-end segments of the Grønne Rende Section.

Rubjerg Knude Fyr stage 5. The continued displacement of RF04 resulted in structural propagation of this sheet above its own piggyback basin with the 'dropped' thrust noses. Stage 5 in the Rubjerg Knude Fyr Section is interpreted to have been contemporaneous with stage 7 in the Stortom Section in which compression brought the thrust sheets into their final, steeply inclined position.

\section{Rubjerg Knude Fyr Section: Summary data \\ Balanced length ( $\mathrm{L}_{\mathrm{b}}$ ): $\quad 525 \mathrm{~m}$ \\ Cross-section length (L): $260 \mathrm{~m}$ \\ Shortening $(\Delta \mathrm{L})$ : $\quad 265 \mathrm{~m}$ \\ Compression: $\quad 50.5 \%$}

\section{Grønne Rende Section}

The impressive imbricate fan composed of 12 upright thin thrust sheets is the essential element in the Grønne Rende Section. As a consequence of the displacement in the imbricate fan, $550 \mathrm{~m}$ of trailing-end lower segments were left behind to be stacked in a duplex below the frontal part of the Stortorn Section (Fig. 113). 
Four stages have been differentiated in the development of the Grønne Rende Section, the first three of which are illustrated in Fig. 115.

Grønne Rende stage 1. The initial thrust-fault framework was a low-angle imbrication, about $20^{\circ}$ on each upper hanging-wall ramp, which rooted down to the upper $10 \mathrm{~m}$ flat level. During thrusting, the upper thrust sheets were split up into three main segments with leading thrust faults below GR02, GR06 and GR11/ GR12 which ramped down to the main level of detachment in the $20 \mathrm{~m}$ flat level. The initial displacementof the imbricate fan isregarded to have been $20 \mathrm{~m}$ on each thrust. This implies that the accumulated displacement sums up to $240 \mathrm{~m}$. GR01 was not affected by thrusting in the first stage, and $240 \mathrm{~m}$ of its lower trailing-end segment was consequently not displaced during this stage.

The sediments of the Rubjerg Knude Fomation attained a maximum thickness of 15 to $20 \mathrm{~m}$ during this stage, with decreased thicknesses on the back of the GR06-GR08 thrust sheets, which were elevated to the highest position.

Grønne Rende stage 2. The imbricate thrusting progressed with a displacement of $50 \mathrm{~m}$ on each thrust. This implies that the hanging-wall flats were fault-bendfolded while they passed the footwall ramps, resulting in a dramatic steepening of the thrust sheets. Below GR10-GR12, the GR07u and GR08u lower segments formed a duplex structure that resulted in elevation and complex ramp-propagation folding of the sheets above. The accumulated displacement implies an increase in length of the trailing-end segment of GR01 in the order of $500 \mathrm{~m}$, allowing for some adjustments due to the irregular duplex deformation. Sediment thicknesses in the piggyback basin in the frontal part of the section increased to $25-30 \mathrm{~m}$.

Grønne Ren de stage 3. Finally, the leading-edge thrust was activated and GR01 was displaced $50 \mathrm{~m}$ up along its footwall ramp. The GR01 thrust roots in the lower $30 \mathrm{~m}$ décollement level, and the displacement of the hanging-wall flat up along the footwall ramp resulted in steepening of all the early-formed thrust elements (GR02-GR13).

The displacements of the individual thrust sheets range between 60 and $70 \mathrm{~m}$. The thrusting resulted in the final, almost vertical, orientation of the thrust sheets. In the rear part of the section, complex deformation of the duplex below GR10-GR13 was reflect- ed in unusual folding of the beds in the GR13 thrust sheet where folds with horizontal axial planes were formed due to gravity collapse of the piggyback basins.

Grønne Rende stage 4. This stage concluded the thrusting of the leading hanging-wall ramp-and-flat over the footwall ramp in the trailing end of the Stenstue Rende Section and the subsequent final rotation of the GR02GR05 thrust sheets. In the trailing end of the section, the RF01 and RF02 sheets concluded the displacement by thrusting from the trailing-end segments of GR12 up over the footwall ramp onto the back of GR13. Moreover, GR13 was rotated into an upright position whereby the horizontal axial planes became vertically orientated (Plate 1).

\section{Grønne Rende Section: Summary data}

$\begin{array}{lr}\text { Balanced length }\left(\mathrm{L}_{0}\right): & 1080 \mathrm{~m} \\ \text { Cross-section length }\left(\mathrm{L}_{1}\right): & 423 \mathrm{~m} \\ \text { Shortening }(\Delta \mathrm{L}): & 657 \mathrm{~m} \\ \text { Compression: } & 60.8 \%\end{array}$

Comment. The lengths are measured from the footwall ramp between RF01 and GR13 to the footwall ramp between GR01 and SS06, near the thrust truncation of the L/R-unconformity.

\section{Stenstue Rende Section}

Two markedly different structural complexes were formed during the development of the Stenstue Rende Section. They were mainly caused by the displacement of the same thrust sheet (SS01) when it was displaced $200 \mathrm{~m}$ over the upper flat on top of the piggyback basin in the Sandrende Section. The frontal part of SS01 above the footwall flat of the SR04 thrust sheet is one of the complexes. The other structural complex is the chaotic breccia and gravity slumping in the northern part of the section that formed as the piggyback thrust sheets were transported over a minor antiformal stack in the central lower part of the section. The progressive dynamic development in the Stenstue Rende Section is described in terms of five stages, the first four of which are illustrated in Fig. 116.

Sten stue Ren de stage 1. Four minor imbrications with an accumulated displacement of $70 \mathrm{~m}$ initiated the 


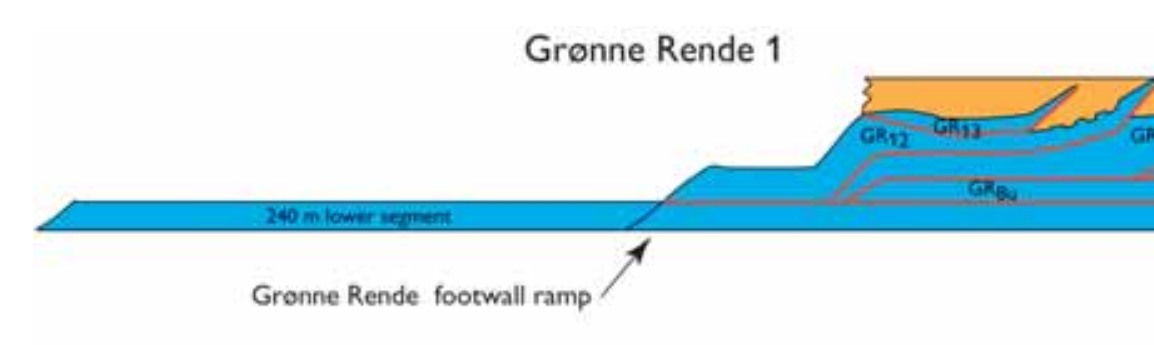

Gronne Rende 2

Fig. 115. Dynamic model of progressive deformation in the Grønne Rende Section illustrated in three sequential restoration cross-sections; the final stage (4) described in the text is not illustrated. The red lines indicate the active displacement surfaces in each deformation stage. Note how the shortening due to the displacement along the $20 \mathrm{~m}$ flat level resulted in the substantial length of the 'left over' lower duplex segment between the 20 and $30 \mathrm{~m}$ flat level.

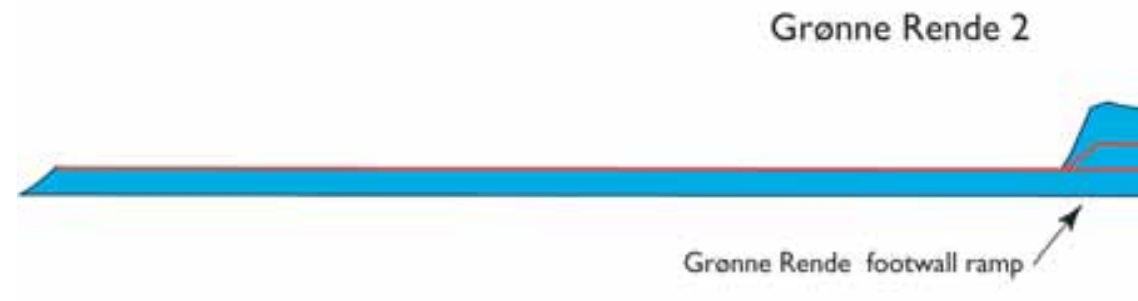

development in the Stenstue Rende Section. At the leading-edge thrust, a minor connection splay separated SSO2 and SS03. Most of the thrusting was located at the upper $10 \mathrm{~m}$ flat level for a distance of about $180 \mathrm{~m}$, in the northern part of which it was eventually rooted down to the lower décollement level. The displacement of the SS05 thrust sheet followed the same system, but with a smaller translation along the upper $10 \mathrm{~m}$ flat level. At the trailing end, SSO6 was thrust up along a steep footwall ramp, and here the formation of duplex structures was probably initiated. The thickness of sediment (Rubjerg Knude Formation) that had accumulated by this stage amounted to $10 \mathrm{~m}$.
Stenstue Rende stage 2. The leading-edge thrusting shifted to the SS01 thrust sheet, which was displaced $20 \mathrm{~m}$ up along the footwall ramp (the trailing end of SR04 in the Sandrende Section). The SS01 thrust fault extended down via an intermediate ramp to the $20 \mathrm{~m}$ flat level, and about $200 \mathrm{~m}$ from the leading footwall ramp it stepped down the lower ramp to the $30 \mathrm{~m}$ décollement level. At the upper hinge of the lower ramp, SS01 was folded into a fault-bend anticline, a small detachment anticline. Along the foreland-dipping limb of the anticline in the SSO1 thrust sheet, a normal fault was formed that displaced the tip of the SS02 thrust sheet. Furthermore, the SS03 thrust sheet 

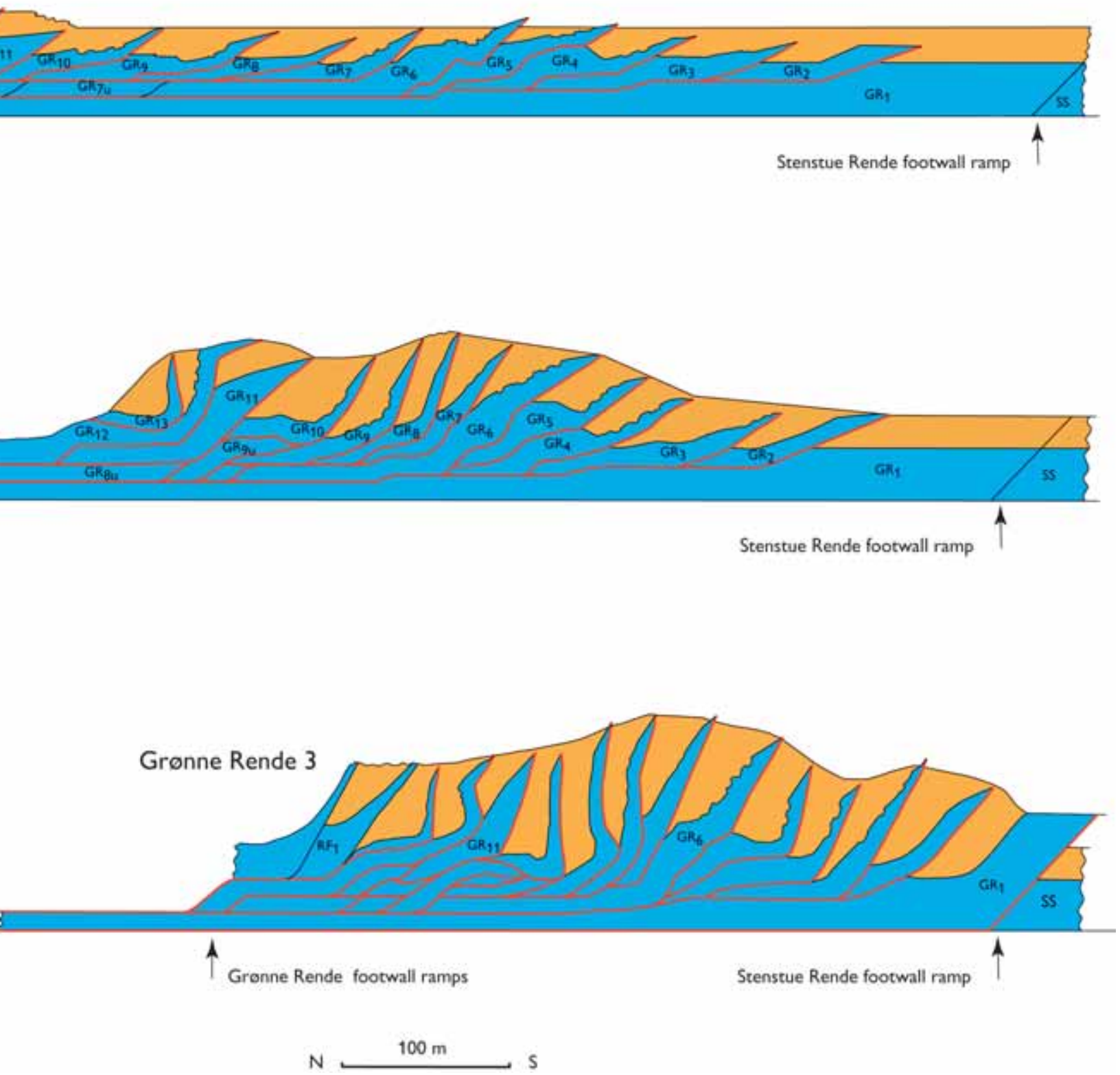

became steeply inclined, and the initial imbrication of the thin SSO3 thrust sheet resulted in the separation of SS03 from SS04.

In the trailing end of the Stenstue Rende Section, duplex stacking of the lower segments in SSO6 resulted in elevation of the L/R-unconformity more than 10 $\mathrm{m}$ above the mean level. The accumulated displacement ranged up to $160 \mathrm{~m}$.

Stenstue Rende stage 3. Thrusting of SS04 progressed on the upper flat over the piggyback basin of SS03 with a frontal displacement of $80 \mathrm{~m}$. The hangingwall flat of SS04 ramped up along the footwall ramp of SSO3 and during this translation the nose of SS05 became fault-bend-folded into a syncline with a steeply dipping southern limb. The trailing end of the SSO4 thrust sheet was translated along the $10 \mathrm{~m}$ flat level; it was pushed from the rear by the ramping of the trailing end of the SS05 thrust sheet whereby the SS06 thrust sheet also steepened up. Sediment thicknesses in the piggyback basins increased to c. $20 \mathrm{~m}$, and the accumulated displacement ranged up to $240 \mathrm{~m}$.

Stenstue Rende stage 4. The dramatic major foreland thrusting of the SS01 thrust sheet, which included about $200 \mathrm{~m}$ displacement of the hanging-wall ramp 


\section{Stenstue Rende 1}

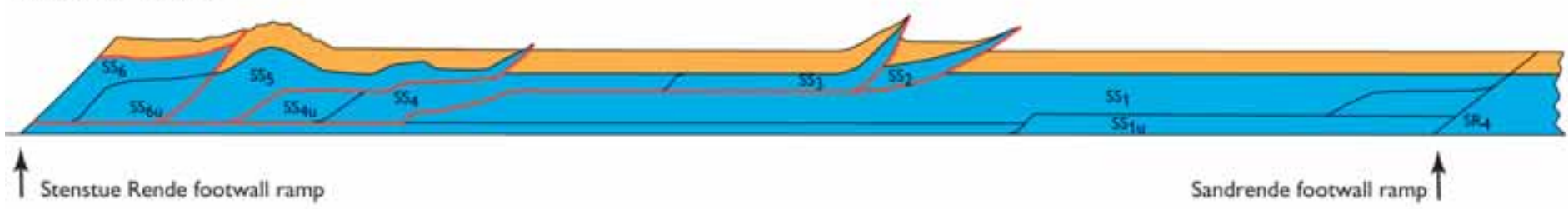

\section{Stenstue Rende 2}

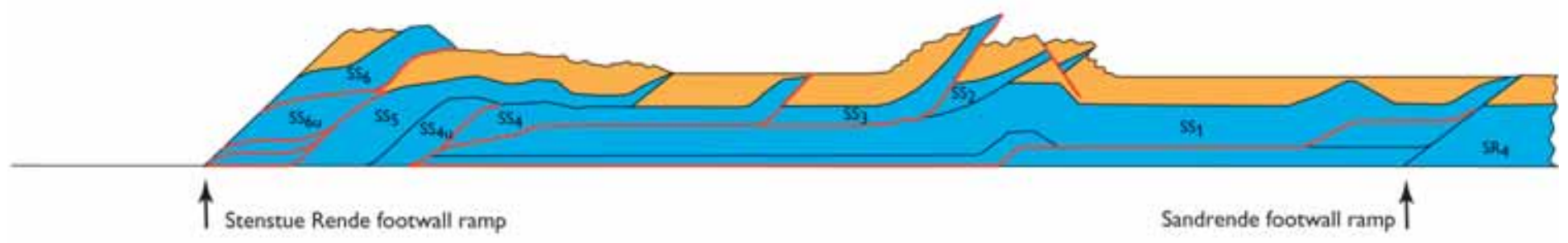

\section{Stenstue Rende 3}

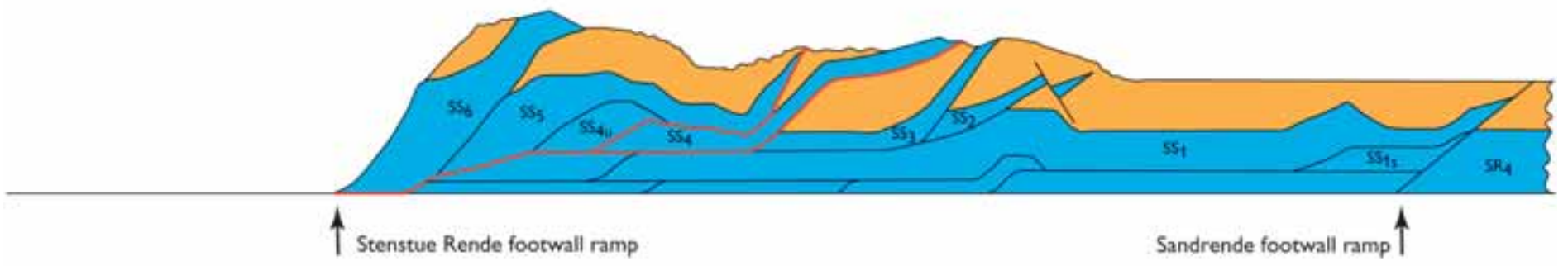

\section{Stenstue Rende 4}

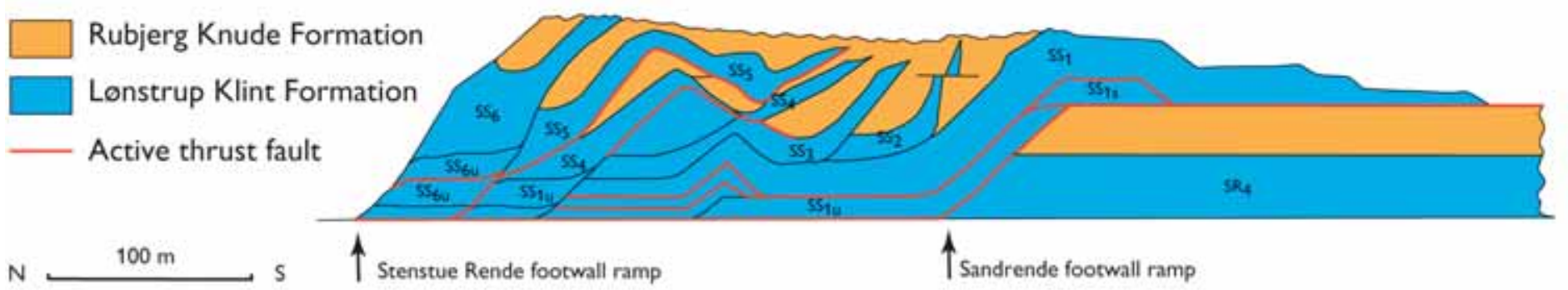

Fig. 116. Dynamic model of progressive deformation in the Stenstue Rende Section illustrated in four sequential restoration crosssections; the final stage (5) described in the text is not illustrated. The cross-sections demonstrate the development stages between the initial and final positions displayed in the balanced and the structural cross-sections in Plate 2 . The red lines indicate the active displacement surfaces in each defomation stage. 
over the piggyback basin of the Sandrende Section, occurred contemporaneously with the formation of an antiformal stack above the trailing end of SSO1. The creation of the antiformal stack had already been initiated by the earlier formation of the minor detachment anticline at the ramp splitting the lower segments of SS01 (the SS01u segments). A duplex duplication of the lower SSO1u segments accentuated the anticline, and finally the SSO3 thrust sheet riding piggyback on SS01 was folded into an anticline with a steep foreland-dipping southern limb (Fig. 90). Along this limb, a normal fault developed that displaced the frontal part of the SSO4 thrust sheet. A chaotic soft sedimentary fault breccia was formed during the stretching and fault separation of SS04 (Fig. 91). Due to an extra push from the rear, the SS05 thrust sheet was displaced a further $30 \mathrm{~m}$ to the south, which resulted in the formation of a huge southerly overturned slump fold above the normal fault zone (Fig. 89).

The accumulated displacement totals about $470 \mathrm{~m}$. The displacement of the SSO1 hanging-wall flat up along the steeply dipping footwall ramp constrains the sequential thrusting of the Stenstue Rende relative to the Sandrende thrusting. Thus stage 4 could not have begun before the maximum sedimentation in the piggyback basin was accomplished in the Sandrende Section. The initial SS01 thrusting could be regarded as a growth fault, whereby the syntectonic accumulation of sand added to the steepening of the footwall ramp. The present vertical to northerly overturned orientation of the SSO1 hanging-wall flat and ramp resulted from differential thrusting and fault-bend of the SS01u lower hanging-wall ramp. Note also the re-orientation of the normal fault at the tip of SSO2, which due to the same deformation was bent into a horizontal position.

Sten stue Rende stage 5. This stage corresponds to stage 6 in the Sandrende Section, wherein the SS01 thrust sheet riding piggyback on SR04 was displaced by normal faulting (Fig. 117, stage 6).

\section{Stenstue Rende Section: Summary data}

$\begin{array}{ll}\text { Balanced length }\left(\mathrm{L}_{0}\right): & 760 \mathrm{~m} \\ \text { Cross-section length }\left(\mathrm{L}_{1}\right): & 285 \mathrm{~m} \\ \text { Shortening }(\Delta \mathrm{L}): & 485 \mathrm{~m} \\ \text { Compression: } & 62.5 \%\end{array}$

Comment. The lengths are measured from the foot- wall ramp between GR01 and SS06 to the footwall ramp between SS01 and SR04. If the compression was calculated from the leading-edge thrust tip of SSO1 to the trailing-end footwall ramp of SSO6, $\mathrm{L}_{1}$ amounts to $455 \mathrm{~m}, \Delta \mathrm{L}=305 \mathrm{~m}$ and the calculated compression would only be $40.1 \%$.

\section{Sandrende Section}

The dynamic development of the Sandrende Section was formerly interpreted as a combination of diapirism and normal faulting caused by volume exchange during thrust propagation (Sadolin et al.1997). The model presented here aims at an explanation of the development purely based on a thin-skinned thrustfault model including differential ramping and duplex formation. Thus, the diapirism is interpreted to be an effect of ramping and fault-bend folding growth, similar to the model of Mitra \& Sussman (1997), but also including mud-mobilisation and exaggeration of backlimb thrusting. The normal faulting occurring in the Sandrende Section is interpreted as the effect of differential ramping of a lower trailing-end segment that created foreland-dipping features above a hangingwall ramp propagation along an intermediate footwall flat. Six stages of dynamic development have been differentiated in the Sandrende Section (Fig. 117).

Sandrende stage 1. After initial deposition of a 3-5 m thick succession of Rubjerg Knude Formation sediments, the SR04 thrust sheet started thrusting about $50 \mathrm{~m}$ over the upper flat. The dip of the footwall ramp was relatively gentle, only c. $14^{\circ}$, and in the $15 \mathrm{~m}$ flat level the thrust fault may be traced along a minor flat segment on top of the lower trailing-end segment of SR03 (SR03u). From the minor intermediate flat, the thrust fault rooted down to the $30 \mathrm{~m}$ décollement level along a $20^{\circ}$ dipping footwall ramp of SR03u. Note that an upper and lower SR04 hanging-wall ramp was introduced subsequently.

Sandrende stage 2. Translation of the lower SR04 hanging-wall ramp along the intermediate flat established the anticline in the central part of the SR04 thrust sheet. The SR03 thrust sheet started to propagate towards its foreland along the upper $10 \mathrm{~m}$ hanging-wall flat, and the frontal part of SR03 was displaced $50 \mathrm{~m}$ over the upper flat on top of the piggyback basin of SR02. The tip of the SR02 thrust sheet propagated up along a growth-fault ramp, which caused the steeply dipping 


\section{Sandrende 1}

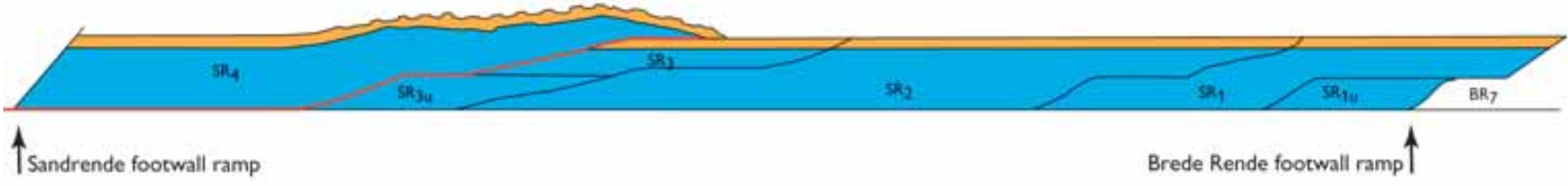

Sandrende 2 \& 3

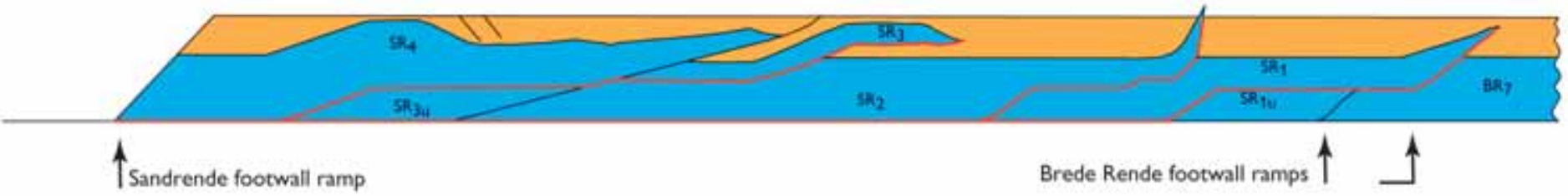

Sandrende 4

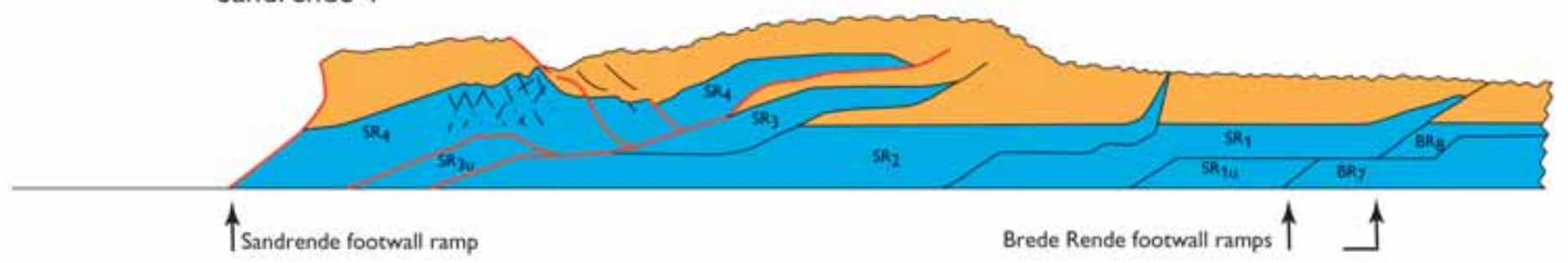

Sandrende 5

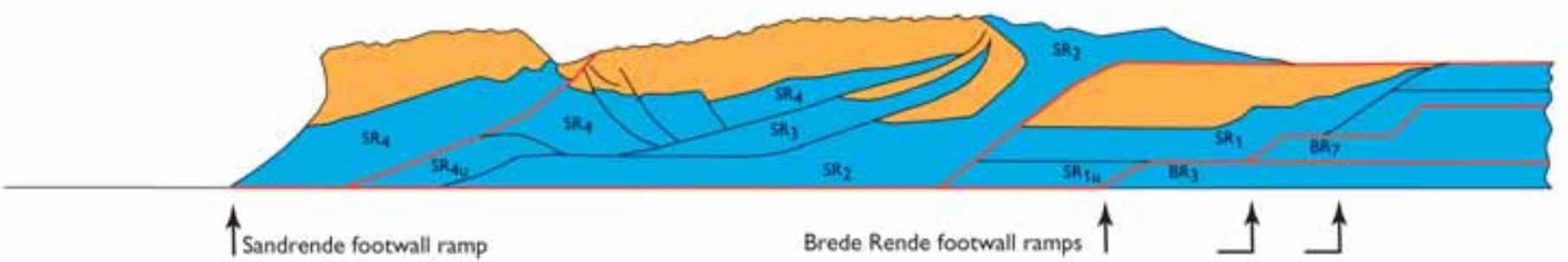

Rubjerg Knude Formation

Lønstrup Klint Formation

Active thrust fault

Sandrende 6

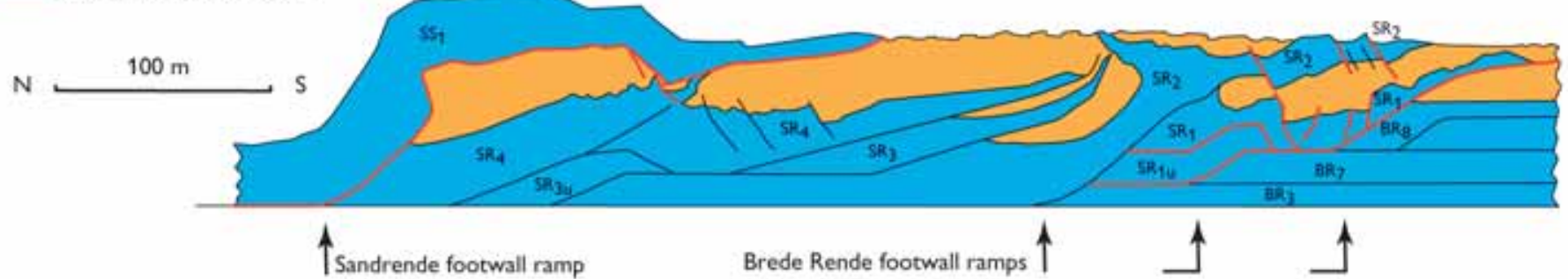


orientation of the northern boundary of the piggybackbasin at the top of the SR01 thrust sheet. Theaccumulated displacement ranged up to about $150 \mathrm{~m}$, including the initial thrusting of SR01.

Sandrende stage 3. During stage 3, the thickness of the sediments of the Rubjerg Knude Formation reached $20 \mathrm{~m}$ in the piggyback basins in the Sandrende Section. In the basin at the top of the SR04 thrust sheet, the thickness varied considerably. The reason for this variation is that the top of the anticline above the SR04 lower hanging-wall ramp was subjected to erosion while deposition continued in the frontal part, south of the anticline, as well as in the basin north of the anticline. On the foreland-dipping flank of the anticline, minor sets of normal growth faults govemed sedimentation (Fig. 87). The tip of the SR04 thrust sheet suffered minor erosion before deposition resumed during thrust propagation. This is documented by the angular onlap relationships described by Sadolin et al. (1997).

Sandrende stage 4 . The thrusting of SR04 continued with $50 \mathrm{~m}$ further displacement. Below the trailing end of the SR04 thrust sheet, the SR03u lower segment was picked up and displaced onto the footwall ramp of SR02. This minor duplex and ramp thrusting accentuated the SR04 hanging-wall anticline, and normal faulting on the foreland-dipping limb progressed. Above the crest of the SR03u detachment anticline, a significant normal fault complex developed. Here in the SR04 thrust sheet, a dense network of conjugate normal faults (Fig. 85) resulted from lateral extension due to flexural slip bend over the upper hinge of the lower footwall ramp.

Sandrende stage 5. The thrusting of SR01 propagated up along the lower and intermediate footwall ramp of the trailing segments of the Brede Rende Section. Dur-

\section{Facing page:}

Fig. 117. Dynamic model of progressive deformation in the Sandrende Section illustrated by five restoration crosssections. Note that stages 2 and 3 include syntectonic sedimentation of the Rubjerg Knude Formation, mainly related to stage 2 , and the thrust-fault configuration concluding stage 3. The cross-sections demonstrate the development stages between the initial and final positions displayed in the balanced and the structural cross-sections in Plate 2. The red lines indicate the active displacement surfaces in each deformation stage. ing this ramping, the hanging-wall flat of SR02 progressed up over the piggyback basin of SR01. The tips of the SR03 and SR04 thrust sheets thus experienced fault bending up along the footwall flat of SR02. The atypical northerly overturned tip at the top of the SR02 sheet probably formed due to accentuated reverse faulting along a former established back-thrust. In the trailing part of the section, a minor satellite splay thrust developed, which broke through the SR04 thrust sheet from thehanging-wall flatto the footwallflat below SS01.

Sandrende stage 6. The final development of the Sandrende Section was dominated by complex duplex formation and fault-bend folding of the SR01 thrust sheet below the frontal part of SR02. During the thrust propagation over the footwall ramp of the trailing-end segments of the Brede Rende Section, a fault-bendfolded syncline was formed in SR01, which resulted in normal fault displacement of the SR01 piggyback basin and the overlying frontal part of the SR02 thrust sheet. Similar normal faulting affected the SS01 thrust sheet, which had over-thrust the piggyback basin on the back of SR04. Due to the intense ramping and folding of SR01 and its underlying duplex (SR01u) into an antiformal stack, mud of the Lønstrup Klint Formation was remobilised in SR01, which intruded through the hanging-wall flat of SR02 to form the diapir in the Sandrende Section.

\section{Sandrende Section: Summary data}

$\begin{array}{ll}\text { Balanced length }\left(\mathrm{L}_{0}\right): & 775 \mathrm{~m} \\ \text { Cross-section length }\left(\mathrm{L}_{1}\right): & 440 \mathrm{~m} \\ \text { Shortening }(\Delta \mathrm{L}): & 335 \mathrm{~m} \\ \text { Compression: } & 43.2 \%\end{array}$

Comment. The lengths are measured from the footwall ramp between SS01 and SR04 to the footwall ramp between SR01 and BR08, at the level where the ramps cut the L/R-unconformity. The volume lost in diapirism has not been considered, and a reduced amount of compression would result by measuring $\mathrm{L}_{1}$ from the tip of the SR01 thrust sheet to the SR04 footwall ramp.

\section{Brede Rende Section}

The development of normal faults associated with foreland-dipping features of hanging-wall ramps trans- 
lated along footwall flats has already been demonstrated in the previous sections. One of the best examples of such a normal fault relationship occurs in the Brede Rende Section. An essential element for this development was the formation of a long thrust sheet, translated laterally more than $150 \mathrm{~m}$ along the upper flat. This is demonstrated by the seven stages of development recognised in the Brede Rende Section, as illustrated by the five cross-sections in Fig. 118.

Brede Rende stage 1. The first stage differentiated here is the initial sedimentation of about 3-5 m of the Rubjerg Knude Formation. This corresponds well with the thickness of sediments deposited initially above the L/R-unconformity in the Sandrende Section; this unit is considered to represent pre-thrust sedimentation, i.e. the sediment record prior to piggyback basin formation.

Brede Rende stage 2. Accepting that the thinnest preserved section of the Rubjerg Knude Fomation indicates the timing of the earliest thrusting, then thrusting in the Brede Rende Section was initiated with the displacement of the BR03 thrust sheet. The frontal part of BR03 was displaced about $50 \mathrm{~m}$ over the upper flat corresponding to the relative foreland in front of the leading edge of thrusting. The BR03 thrust fault probably rooted down to the $30 \mathrm{~m}$ décollement level. However, translation in the upper $10 \mathrm{~m}$ flat level cannot be excluded, and in this case the beds disturbed by hydrodynamic brecciation might be interpreted as thrust flats. In the trailing end of the section, the BR06 hanging-wall ramp was the next thrust to break through and initiate the translation along the upper flat.

Brede Rende stage 3. The BR06 thrust sheet was further displaced c. $50 \mathrm{~m}$ over the upper flat. The trailing end of BR06 was separated by a splay thrust at the footwall ramp, along which the BR07 thrust sheet propagated contemporaneously with piggyback thrusting of BR08. This stage is equivalent to the frontal thrusting during stage 5 in the Sandrende Section.

Brede Rende stage 4. Sediment accumulation in the piggyback basins increased up to about $15 \mathrm{~m}$. The marked difference in thickness of deposits is clearly seen by comparing the BR05 thrust sheet with the BR06 thrust sheet. The roof of BR05 was obviously capped at an earlier stage than BR06 where sediments accumulated to more than twice the thickness of that in BR05.
Brede Rende stage 5 . With a displacement of about 60 $\mathrm{m}$, the BR05 thrust sheet propagated up along the footwall ramp of BR04 and onto the upper flat on top of the BR04 thrust sheet. Translation of the BR06 thrust sheet progressed c. $60 \mathrm{~m}$ along the upper flat. The thrusting rooted down to the $20 \mathrm{~m}$ flat level on top of the trailing-end segment of the BR03 thrust sheet (BR03u). The accumulated displacement amounted to $150 \mathrm{~m}$, including the ramping and translation of the BR07 thrust sheet along the same $20 \mathrm{~m}$ flat level.

Brede Rende stage 6 . After the thrusting of BR05 and BR06 ceased, the BR04 thrust sheet was translated c. $80 \mathrm{~m}$. The BR04 thrust fault included three ramps: an upper gently dipping ramp from the upper flat to the 5-10 m flat level, an intermediate ramp-bend of the BR03 thrust sheet due to the presence of the formerly established BR02 footwall ramp, and a lower ramp from the $10 \mathrm{~m}$ to the $20 \mathrm{~m}$ flat level. The translation of the BR04 lower hanging-wall ramp along the footwall flat of BR03 created the foreland-dipping bend that, combined with the bend due to the BR03 ramping, formed a syncline in front of the BR04 ramp anticline. The normal fault created parallel to the foreland-dipping features displaced the tip of the BR06 thrust sheet. The vertical offset on the normal fault amounted to $\mathrm{c}$. $20 \mathrm{~m}$, which also included the displacement caused by the offset in front of the BR05 thrust tip.

Brede Rende stage 7. Finally, the leading-edge thrusting of the section propagated over the trailing end of the Kramrende Section. Above the footwall ramp of BR01, a minor antiformal stack was formed and subsequently an irregular duplex formation affected the BR01 thrust sheet during the last stage of deformation in the Brede Rende Section. This phase developed into diapirism that intruded towards the thrust fault between BR01 and BR02.

\section{Facing page:}

Fig. 118. Dynamic model of progressive deformation in the Brede Rende Section illustrated in five sequential restoration cross-sections. The cross-sections demonstrate seven stages in the development between the balanced cross-section and the structural cross-section (Plate 2). The red lines indicate the active displacement surfaces in each deformation stage. Note that significant normal faulting occurred in the Brede Rende Section during stages 5 and 6 while the hanging-wall anticline in the middle part of the BR04 thrust sheet was formed. 
Brede Rende 1 \& 2

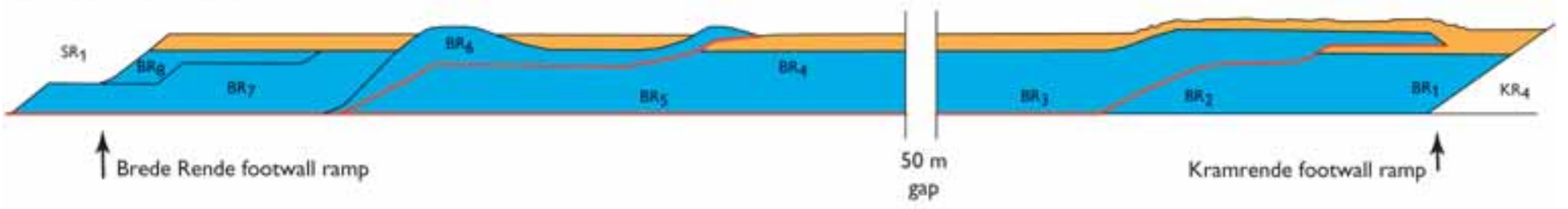

Brede Rende 3 \& 4
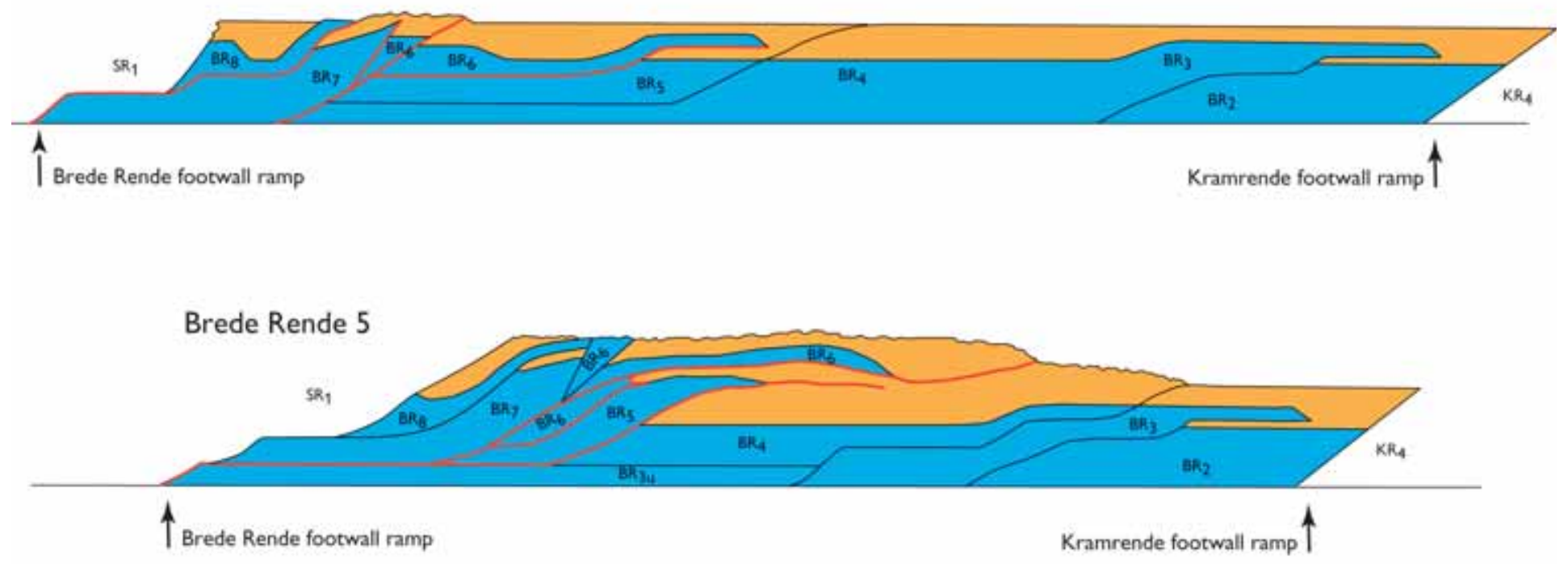

Brede Rende 6

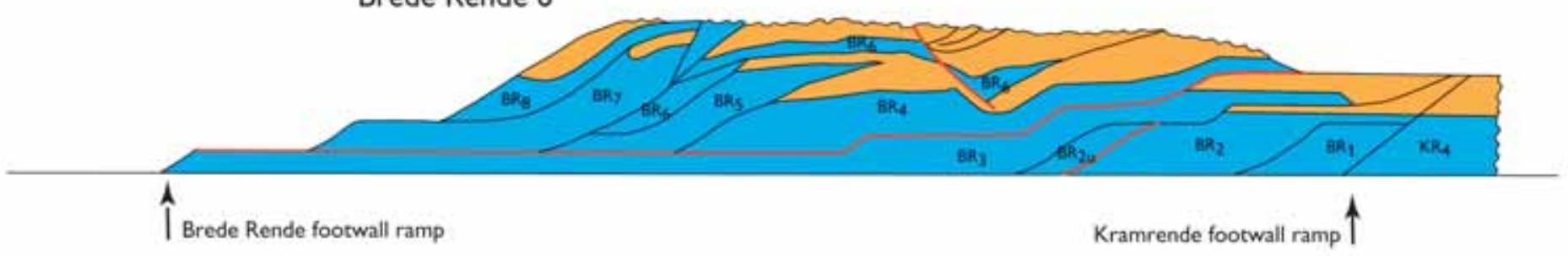

Rubjerg Knude Formation

Lonstrup Klint Formation

Active thrust fault

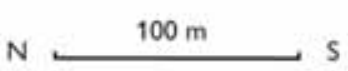

ᄂ

Brede Rende 7 


\section{Brede Rende Section: Summary data}

$\begin{array}{ll}\text { Balanced length }\left(\mathrm{L}_{\mathrm{b}}\right): & 815 \mathrm{~m} \\ \text { Cross-section length }\left(\mathrm{L}_{\mathrm{H}}\right): & 440 \mathrm{~m} \\ \text { Shortening }(\Delta \mathrm{L}): & 375 \mathrm{~m} \\ \text { Compression: } & 46.0 \%\end{array}$

\section{Kramrende Section}

In the central part of the Kramrende Section, a major diapir developed during the progressive thrusting. The Kramrende diapir was the most distally located diapir in the thin-skinned thrust-fault system indicating that a certain amount of ramp propagation from a deeper décollement level (at least $30 \mathrm{~m}$ flat level) was needed for macroscopic-scale diapirism. South of the Kramrende Section, the décollement level gradually changed to a shallower position and the intensity of ramping decreased. Seven stages of dynamic development have been differentiated in the Kramrende Section, as illustrated in the five cross-sections in Fig. 119.

Kramrende stage 1. The thrusting in the Kramrende Section was initiated with leading-edge propagation along the KR01 thrust fault, which constituted an upper footwall ramp with a dip of $10^{\circ}$, a minor intermediate flat at the $15 \mathrm{~m}$ flat level, and a c. $15^{\circ}$ dipping lower ramp connecting the thrust fault to the $30 \mathrm{~m}$ décollement level. The displacement was in the order of $100 \mathrm{~m}$ along the upper flat, where almost no sedimentation of the Rubjerg Knude Formation took place.

Kramrende stage 2. Subsequent to the early stage thrusting, the lowermost $10 \mathrm{~m}$ of the Rubjerg Knude Formation was deposited; the sediment thickness in the KR01 piggyback basin was probably a little less.

Kramrende stage 3. The KR01 thrusting progressed about $60 \mathrm{~m}$ over the upper footwall flat of what was to become the MB04 thrust sheet, and the trailing end of the KR01 thrust sheet was elevated to the $15 \mathrm{~m}$ flat level by ramp propagation over the lower footwall ramp of MB04. A small duplex segment (KR01s) under the middle part of the KR01 thrust sheet was picked up in the thrusting and displaced to the upper footwall ramp hinge, where it formed a minor angular anticline. In the syncline between the anticline and the footwall ramp of KR01, the thickness of piggyback basin sediment accumulation increased to about $15 \mathrm{~m}$ before the KR02 thrust sheet propagated c. $50 \mathrm{~m}$ up along the ramp, and the KR02 hanging-wall ramp partly capped the KR01 piggyback basin. The accumulated displacement ranged up to about $260 \mathrm{~m}$.

Kramrende stage 4 . Thrusting of the KR03 thrust sheet was initiated up along the northerly dipping footwall flat of KR02. The KR03 thrust fault included an upper and a lower relatively steep (c. $23^{\circ}$ ) ramp. The top of the KR02 thrust sheet was probably exposed to erosion, and the Rubjerg Knude Formation is thus missingin this part of the section. The piggyback sediment pile increased to a thickness of $20 \mathrm{~m}$, as indicated by the sedimentary section preserved above the L/R-unconformity at the top of the KR04 thrust sheet. From the trailing end of the KR01 thrust sheet, diapirism intruded through the footwall ramp and irregular mud diapirism developed in the KR02 thrust sheet.

Kramrende stage 5. With a displacement of c. $30 \mathrm{~m}$, KR03 thrusting propagated over the two ramps that resulted in the fault-bend folding of two anticlines separated by an intervening syncline.

Kramrende stage 6. The KR04 thrust sheet was thrust over the fault-bend-folds formed in stage 5, simultaneously with limited continuation of KR03 thrusting. Minor irregular duplex formation started to develop into mud mobilisation at the trailing end of the KR02 and KR04 thrust sheets.

Kramrende stage 7. The final thrust propagation of the KR03 thrust sheet concluded with a displacement of $30 \mathrm{~m}$ up along the footwall flat of KR02. At the bend between the footwall flat and the footwall ramp of KR02, a remarkable set of reverse faults developed (Fig. 72). The KR04 thrust sheet, carried piggyback on KR03, was also displaced by the reverse faulting, a fact that testifies to the relative timing of KR04 piggyback thrusting and KR03 ramp propagation. The reverse faults are regarded as back-limb thrusts similar to the back-thrust features mentioned in stage 5 of the Sandrende Section. Minor back-limb reverse faults

\section{Facing page:}

Fig. 119. Dynamic model of progressive deformation in the Kramrende Section illustrated in five sequential restoration cross-sections. The cross-sections demonstrate seven development stages, of which stage 2 represents a purely depositional phase and stage 4 only includes minor displacement. The red lines indicate the active displacement surfaces in each deformation stage. 
Kramrende 1 \& 2
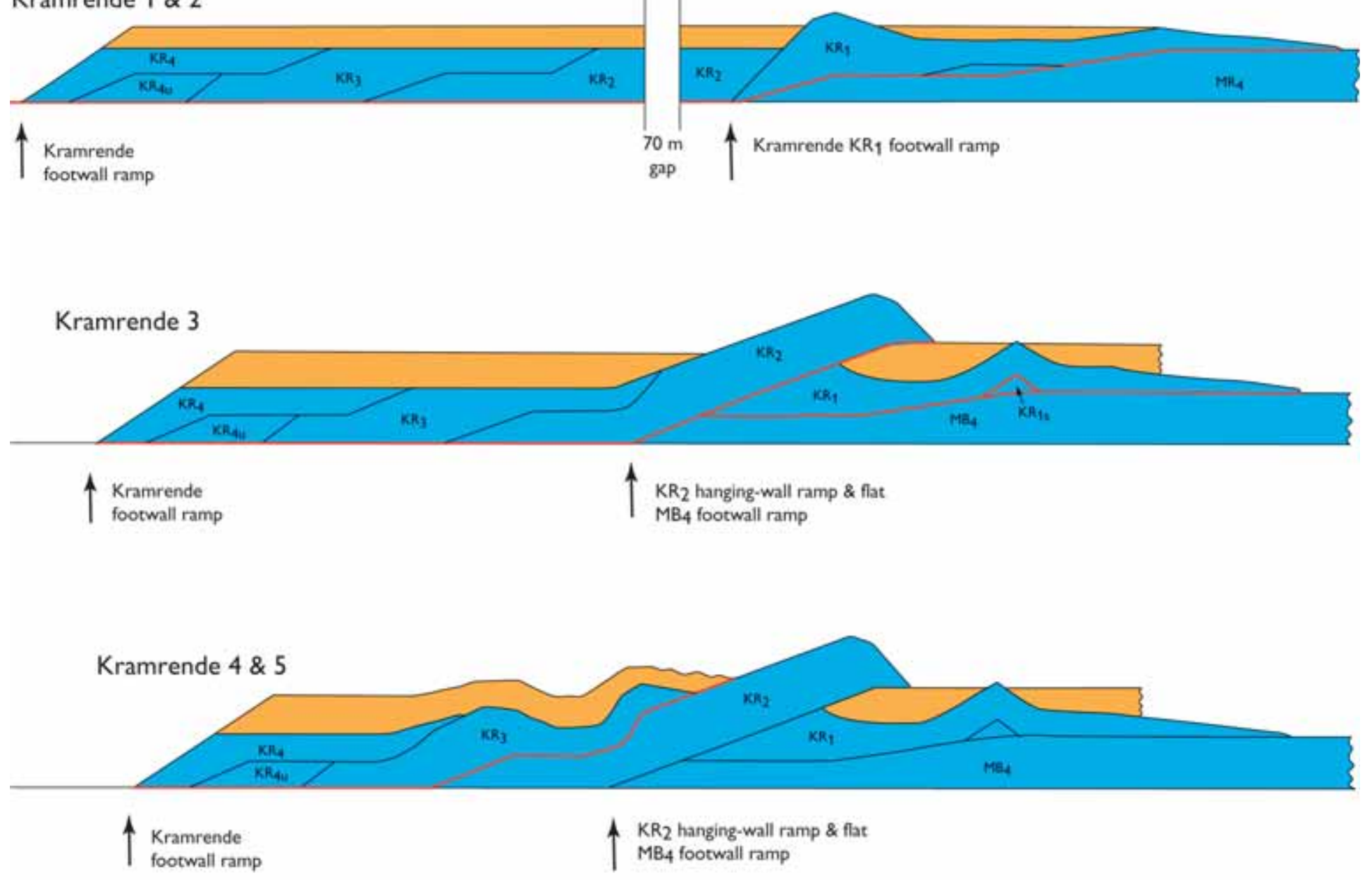

Kramrende 6
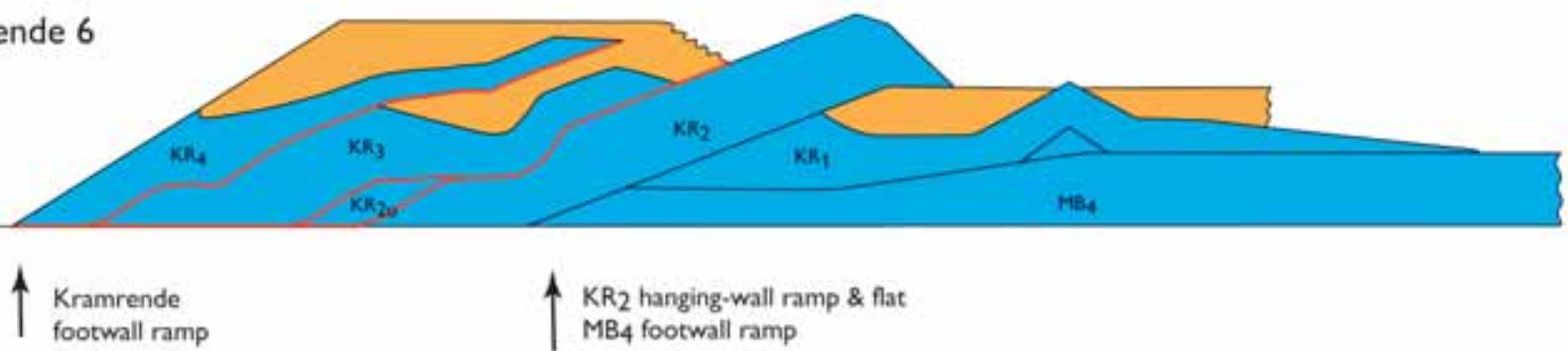

$K_{2}$ hanging-wall ramp \& flat

$\mathrm{MB}_{4}$ footwall ramp

Rubjerg Knude Formation

Lønstrup Klint Formation

Kramrende 7

Active thrust fault

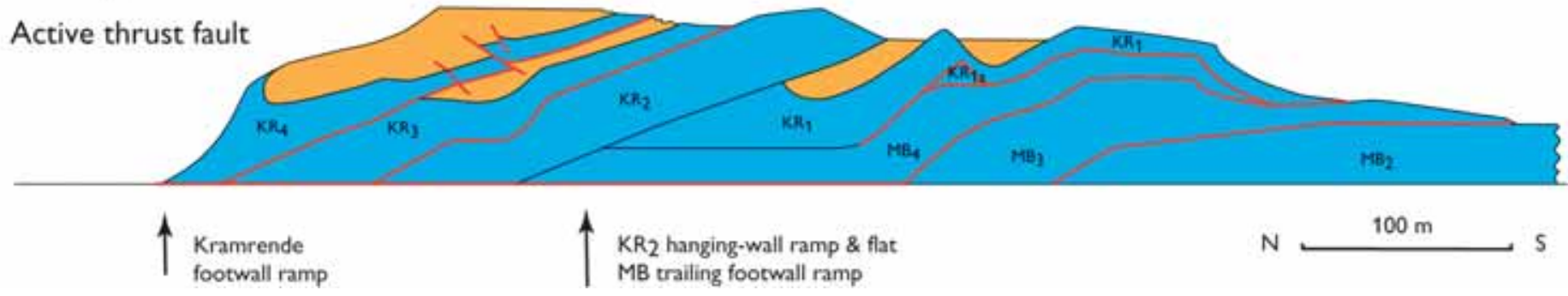




\section{Martørv Bakker 1}

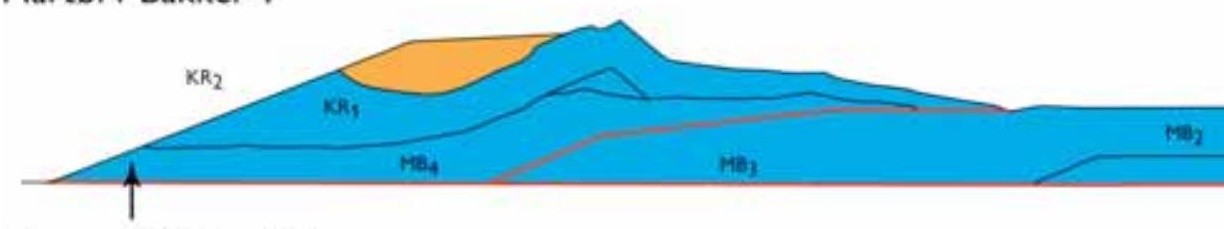

Kramrende / Martorv Bakker

footwall ramp

Fig. 120. Dynamic model of progressive deformation in the Martørv Bakker Section illustrated in three sequential restoration cross-sections. The cross-sections demonstrate four stages in the development between the balanced cross-section and the structural cross-section (Plate 2). The red

lines indicate the active displacement surfaces in each deformation stage. Note the significant depression formed in the hanging-wall block south of the Martørv Bakker normal fault. In this depression, diamictites interlayered with slump-slides were deposited.

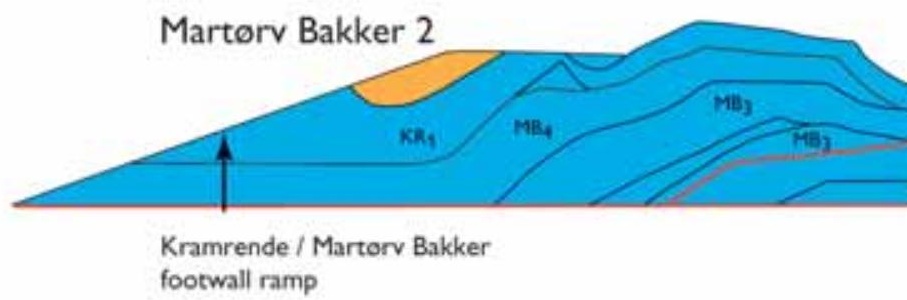

Martørv Bakker 3 \& 4

Kramrende / Martorv Bakker footwall ramp also developed at the crest of the fault-bend-folded KR01 thrust sheet. Polyphase diapirism evolved in the trailing end of the KR03 and KR04 thrust sheets, such that the primary thrust-fault framework was partially destroyed.

\section{Kramrende Section: Summary data}

$\begin{array}{ll}\text { Balanced length }\left(\mathrm{L}_{0}\right): & \text { c. } 600 \mathrm{~m} \\ \text { Cross-section length }\left(\mathrm{L}_{1}\right): & \text { c. } 300 \mathrm{~m} \\ \text { Shortening }(\Delta \mathrm{L}): & \text { c. } 300 \mathrm{~m} \\ \text { Compression: } & \text { c. } 50 \%\end{array}$

Comment. The lengths are measured from approximate positions on the footwall ramps bounding the Kramrende Section and the data must therefore be regarded as tentative estimates.

\section{Martørv Bakker Section}

The development in the Martørv Bakker Section was dominated by the translation of a thrust sheet that was more than $600 \mathrm{~m}$ long and only $20-30 \mathrm{~m}$ thick. During nearly $400 \mathrm{~m}$ of displacement towards the foreland, a lower segment transformed into a duplex that ramped at a relatively late stage and created a fault- 

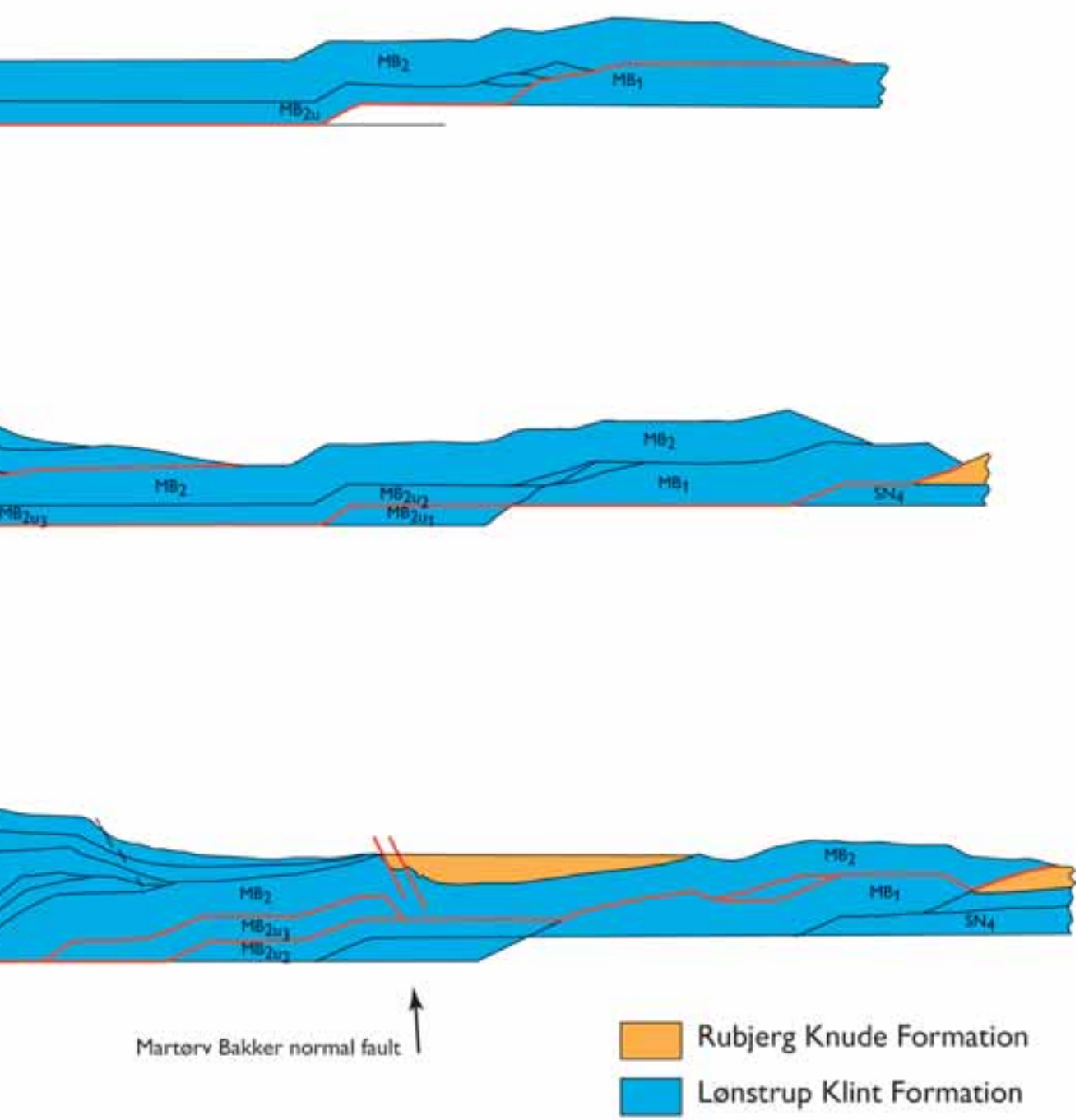

Active thrust fault

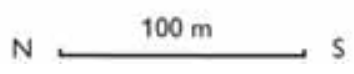

bend-fold anticline and syncline pair. At the upper surface of the intervening limb between the fold pair, a foreland-dipping normal fault was formed, rather similar to the structural complex formed in the Brede Rende Section. Simultaneously with the sedimentation of a diamictite, three slump-slides filled the piggyback basin developed in a syncline created at the top of the hanging-wall block of the normal fault. The sequential restoration stages are illustrated in three cross-sections in Fig. 120.

Martørv Bakker stage 1. Thrusting in the Martørv Bakker Section started with foreland thrusting of MB02, and translation of the trailing-end duplex that consti- tuted the KR01 thrust sheet emplaced piggyback on the MB04 thrust sheet, thrust up along the footwall ramp of MB03. The more than $600 \mathrm{~m}$ long MB02 thrust sheet was displaced c. $105 \mathrm{~m}$ over the footwall flat of MB01. The MB02 thrust fault included two ramps, an upper footwall ramp of MB01 and a lower ramp between the $20 \mathrm{~m}$ flat level and the $30 \mathrm{~m}$ décollement level. The lower ramp was located below the central part of the MB02 thrust sheet, where it acted as the final step for the décollement level change to the 20 $\mathrm{m}$ footwall flat level. It is thought unlikely that significant sedimentation occurred in the section during this stage. 
Martørv Bakker stage 2. The MB01 thrust sheet was displaced about $100 \mathrm{~m}$ over the foreland of the Stensnæs Section along the leading-edge thrust. The MB01 thrust was rooted down to the $20 \mathrm{~m}$ flat level, and it can be traced further on to the $30 \mathrm{~m}$ décollement level by passing the central lower footwall ramp of MB02. Minor adjustments along the hanging-wall flat resulted in formation of small duplexes along the thrust fault. In the trailing end of the section, the MB03 thrust sheet was thrust up over the footwall ramp of MB02, whereby an antiformal stack was formed due to the folding that also involved the MB04 and KR01 thrust sheets. At the base of the MB03 thrust sheet, the lower segments formed an irregular duplex, which accentuated the antiformal stack. The accumulated displacement ranged up to $290 \mathrm{~m}$.

Martørv Bakker stage 3. The final thrusting of the Martørv Bakker Section was concluded by nearly 100 $m$ displacement of the MB02 thrust sheet. The frontal hanging-wall ramp-and-flat was thrust over the piggyback basin of the SN04 thrust sheet in the Stensnæs Section. During the thrusting, the lower segment $\mathrm{MB} 02 \mathrm{u}$ was activated and formed a fault-bend-folded lower duplex. Above the hanging-wall ramp of the trailing-end segment (MB02u3), an anticline was formed at the surface of MB02 and a subsequent syncline above the hanging-wall/footwall flat became a piggyback basin.

Martørv Bakker stage 4. The foreland-dipping limb of the fold pair at the top of the MB02 thrust sheet developed into a southerly dipping normal fault. The c. 10 $\mathrm{m}$ deep piggyback basin was filled with diamictitic deposits and slump-sheets that glided down from the top of the antiformal stack. Deformation in the Martørv Bakker Section concluded with the steepening up of the leading-edge thrust structures due to ramp bending in the Stensnæs Section.

\section{Mar tørv Bakker Section: Summary data}

$\begin{array}{lr}\text { Balanced length }\left(\mathrm{L}_{0}\right): & 1065 \mathrm{~m} \\ \text { Cross-section length }\left(\mathrm{L}_{1}\right): & 675 \mathrm{~m} \\ \text { Shortening }(\Delta \mathrm{L}): & 390 \mathrm{~m} \\ \text { Compression: } & 36.6 \%\end{array}$

Comment. The lengths are measured from the tip of the leading-edge hanging-wall ramp to the upper bend of the footwall ramp of the MB04 thrust sheet.

\section{Stensnaes Section}

In the Stensnæs Section, a number of conspicuous flexural slip folds occur which are interpreted to have resulted from the deformation that accompanied sequential footwall ramp collapse and subsequent ramp displacement of minor duplexes. It is significant that they occur in relation to the final ramping from the lower $20 \mathrm{~m}$ flat level to the upper $10 \mathrm{~m}$ flat level. Eight stages have been differentiated in the development of the Stensnæs Section, of which stages 2, 4 and 6-8 are illustrated by the cross-sections in Fig. 121.

Stensnæs stage 1. In contrast to the Martørv Bakker Section, an initial sediment thickness of $5 \mathrm{~m}$ of the Rubjerg Knude Formation is thought to have covered the Stensnæs Section. It should be noted, however, that typical Lønstrup Formation facies grade upwards into typical Rubjerg Knude Formation facies in this distal part of the Rubjerg Knude Glaciotectonic Complex; the L/R-unconformity is not clearly developed, and location of the formation boundary can be difficult. The affinities of the sediment packet referred to above are thus debatable.

Stensnæs stage 2. Thrusting in the Stensnæs Section was initiated with c. $100 \mathrm{~m}$ displacement of the SN02 thrust sheet over the upper flat. The thrust fault ramped down to the $10 \mathrm{~m}$ flat level, which separated the upper and lower segments of the SN04 thrust sheet, simultaneously with stacking the SN03 thrust sheet into a northerly dipping duplex complex along the footwall ramp of SN01.

Stensnæs stage 3. Accumulation of the Rubjerg Knude Formation increased to a sediment thickness of $10 \mathrm{~m}$. Sedimentation was restricted to the piggyback basin of the SN04 thrust sheet, as well as on the foreland south of the frontal tip of the SN02 thrust sheet.

Stensnæs stage 4 . The piggyback basin on the back of SN04 was sealed in by the overthrusting of the MB02 thrust sheet; this is equivalent to stage 3 in the Martørv Bakker Section.

Sten snæs stage 5. As a trailing-end structural complex to the Ulstrup Section, the thrust sheets of the Stensnæs Section were translated together with the UL02 thrust sheet over the Ulstrup footwall ramp onto the hanging-wall flat of the foreland. During ramping, the SN01 and SN03 thrust sheets were separated into small duplex segments. Flexural-slip folding and polyphase 


\section{Stensnæs 2}

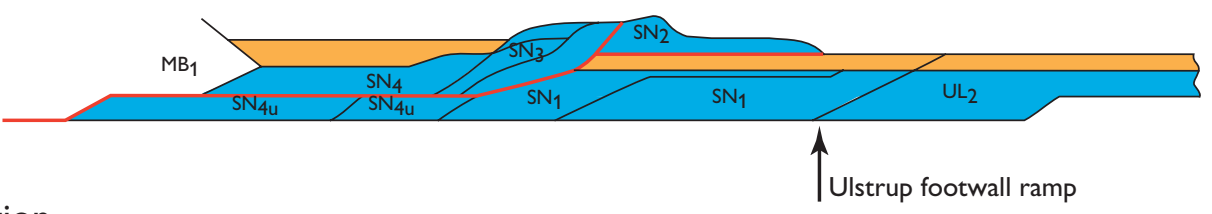

\section{Rubjerg Knude Formation}

\section{Lønstrup Klint Formation}

\section{Active thrust fault}
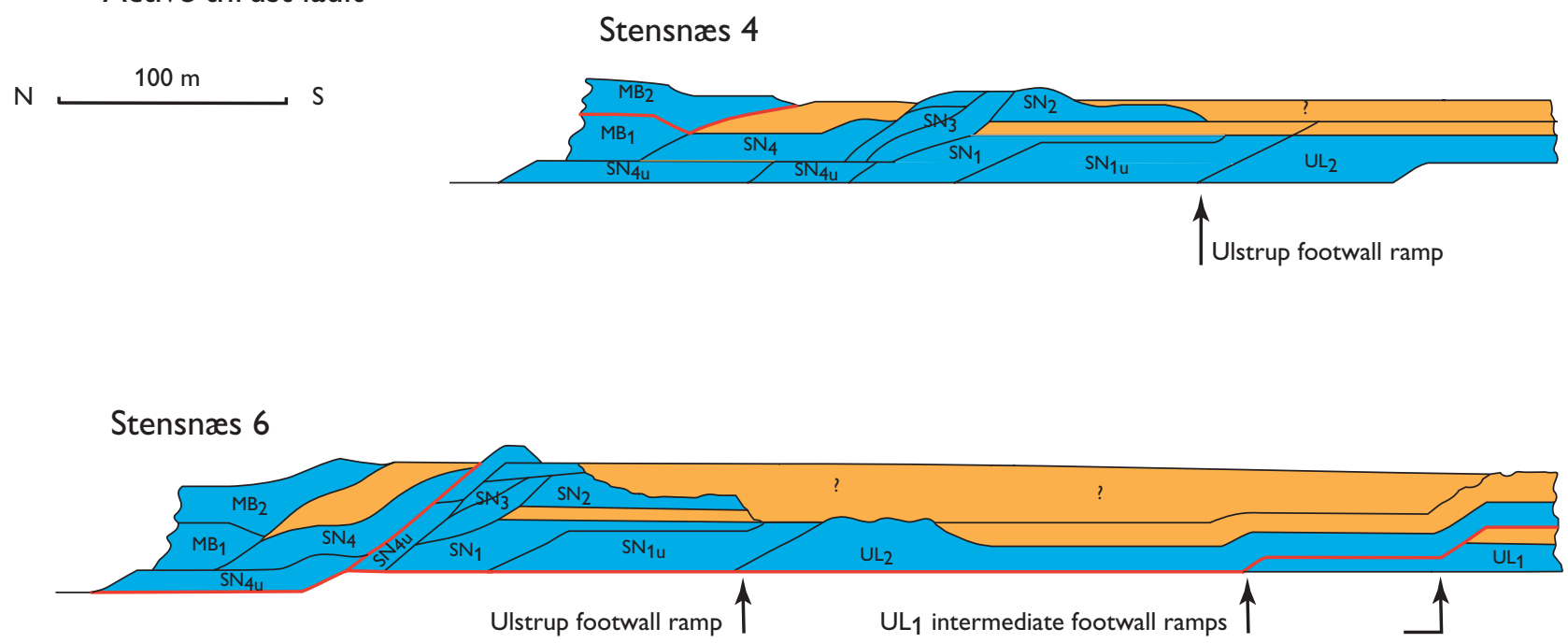

Stensnæs 7 \& 8

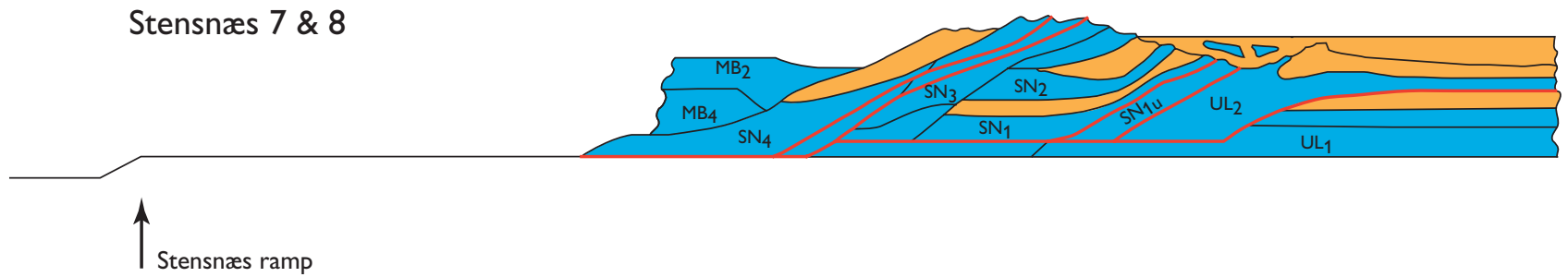

Fig. 121. Dynamic model of progressive deformation in the Stensnæs Section illustrated in four sequential restoration cross-sections. The cross-sections demonstrate five of the eight stages in the development described in the text between the balanced cross-section and the structural cross-section (Plate 2). The red lines indicate the active displacement surfaces in each deformation stage.

hydrodynamic brecciation resulted from the ramping (Figs 53, 57, 58). The accumulated displacement ranged up to $35 \mathrm{~m}$, whereas the length of the hanging-wall flat in the $10 \mathrm{~m}$ flat level amounted to $500 \mathrm{~m}$. At the leading edge of thrusting, the UL02 thrust sheet initiated the thrusting up over a stepwise ramp.

Sten snæs stage 6 . During this stage, about $10 \mathrm{~m}$ of the Rubjerg Knude Formation was deposited in the piggyback basin at the top of the SN02 thrust sheet. The sedimentation level was probably up to $20 \mathrm{~m}$ above the L/R-unconformity, inferred from the elevated position of the SNO2 thrust sheet. However, this is uncertain and the sediments were either never deposited or eroded away during later thrust elevation. In the northern part of the section, the SN04 thrust sheet propagated up along the footwall ramp of the earlier created SN02-SN03 duplex. This resulted in fault-bend folding of the SN04 thrust sheet and its piggyback basin as well as the overlying MB02 thrust sheet. This 


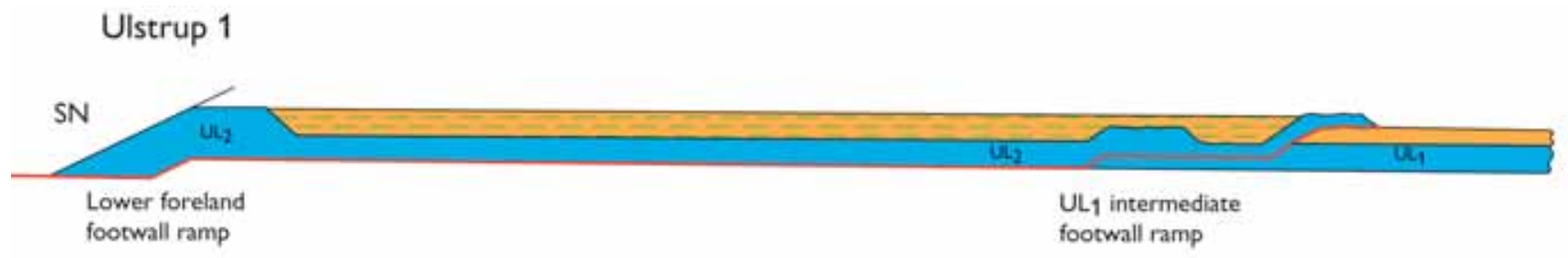

Ulstrup 2

Ulstrup 3

\section{Ulstrup glaciolacustrine beds}

\section{Ulstrup glaciofluvial beds}

Rubjerg Knude Formation

Lonstrup Klint Formation

\section{Active thrust fault}

$N \longleftarrow$ S

\section{Ulstrup 5}

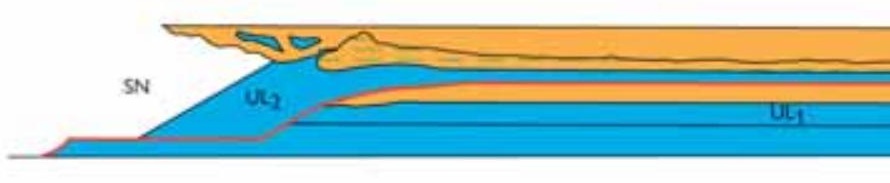

stage correlates with stages 3-6 in the Martørv Bakker Section.

Sten snæs stage 7. The SN01 thrust sheet was displaced about $50 \mathrm{~m}$ overits lower segment (SN01u), and together they were thrust onto the footwall ramp-and-flat ofthe UL02 thrust sheet. During the thrust-fault propagation of the UL02 thrust sheet over the footwall ramp of UL01, the SN01 and SN02 thrust sheets, piggyback translated on UL02, were bent into c. $30^{\circ}$ dipping position. Finally, the SN04 thrust sheet was displaced up along the footwall ramp of SNO3 during differential duplex formation along the SNO4 hanging-wall ramp.

Sten snæs stage 8. The frontal parts of the SN01, SN02 and SN03 thrust sheets, as well as the anticlinal crest of the UL02 thrust sheet (formed above the upper hinge of footwall ramp of UL01), were significantly eroded, and a local piggyback basin was fomed above the transition between the Stensnæs and Ulstrup Sections. To the north of this piggyback basin, the elevated and exposed tips of the SN02-SN04 thrust sheets gravity-slumped out into the basin, where they were deposited as olistoliths, 1-5 $\mathrm{m}$ in size.

\section{Stensnæs Section: Summary data}

Balanced length $\left(\mathrm{L}_{0}\right): \quad 350 \mathrm{~m}$

Cross-section length (L): $180 \mathrm{~m}$

Shortening $(\Delta \mathrm{L})$ : $\quad 170 \mathrm{~m}$

Compression: $\quad 48.6 \%$ 
Fig. 122. Dynamic model of progressive defomation in the Ulstrup Section illustrated in four sequential restoration crosssections. The cross-sections demonstrate four of the eight stages in the development described in the text between the balanced cross-section and the structural cross-section (Plate 2). The red lines indicate the active displacement surfaces in each deformation stage.
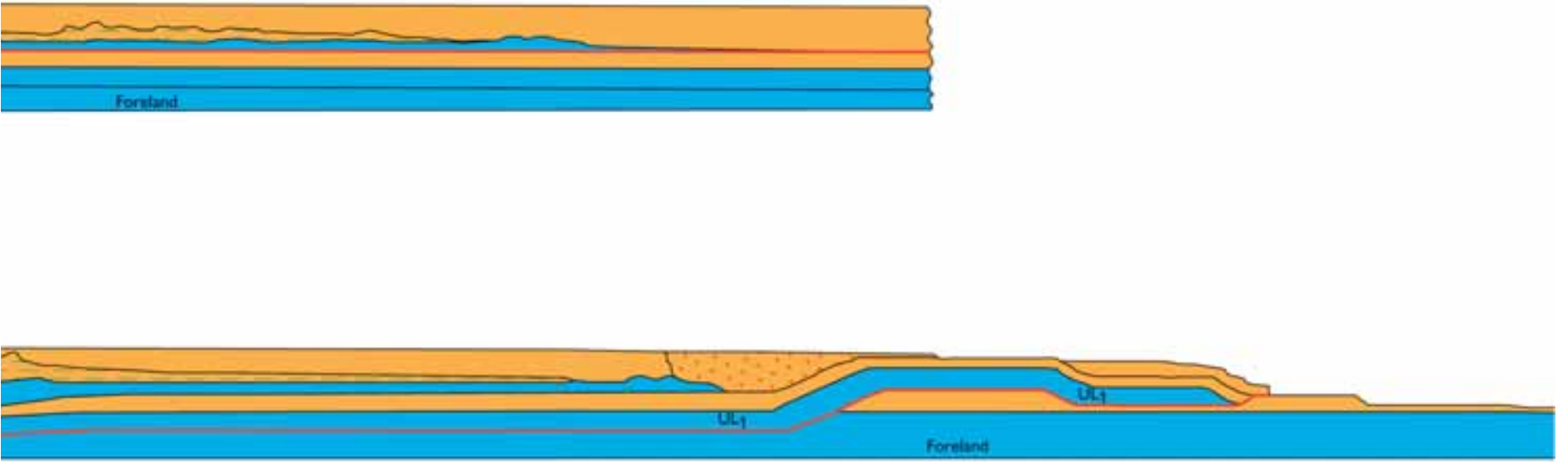

\section{Ulstrup Section}

Thin-skinned thrusting in the Ulstrup Section involved the remarkable translation of extensive, thin thrust sheets over the footwall flat of the foreland. Cohesion of the thrust sheet was probably increased by ground frost in the upper part of the thrust sheet, while the hanging-wall ramp-and-flatslid on a thin zone of mobilised mud. During translation, piggyback sedimentation varied considerably. Six stages have been differentiated in the development of the Ulstrup Section; stages 1-3 and 5 are illustrated by the cross-sections in Fig. 122 (see also Fig. 121).

Ulstrup stage 1. Thrusting in the Ulstrup Section initiated with frontal ramping of the UL02 thrust sheet over a two-stepped footwall ramp of what was to become the UL01 thrust sheet. This ramping resulted in the formation of two, fault-propagating folded anticlines, which were separated by a shallow, broad syncline. The leading edge of the UL02 hanging-wall ramp was displaced about $25 \mathrm{~m}$ over the c. 5-10 m thick Rubjerg Knude Formation deposited in the foreland (at the top of UL01). The UL02 hanging-wall flat extended along the upper $10 \mathrm{~m}$ flat level for about $400 \mathrm{~m}$, terminating to the north at the foreland footwall ramp rooting down to the $20 \mathrm{~m}$ décollement level. Thrust propagation up over this ramp formed a hanging-wall anticline at the trailing end of the UL02 thrust sheet. Between the anticline at the trailing end and the anticline at the upper footwall ramp of UL01, a piggyback basin formed in which glaciolacustrine sediments were deposited to form the small, ephemeral Ulstrup lake. 
Ulstrupstage 2. Thrusting along the UL02 hanging-wall ramp-and-flatprogressed with an accumulated displacementof $230 \mathrm{~m}$. The glaciolacustrinedeposits of the ephemeral Ulstrup lake participated in the ramp-propagating-folding. During translation along the upper $10 \mathrm{~m}$ flat level, the trailing end of the UL02 thrust sheet was probably covered by sediments, which subsequently became eroded. This event in the Rubjerg Knude Formation corresponded to stage 6 in the Stensnæs Section.

Ulstrup stage 3. The long lateral thrusting of the UL02 thrust sheet along the upper flat resulted in $550 \mathrm{~m}$ of displacement, and at the lower trailing end, the hanging-wall ramp became detached to the upper footwall ramp of UL01. Above this ramp, conspicuous flexuralslip folds, similar to the folds developed in the Stensnæs Section, were formed in the UL02 thrust sheet.

Ulstrup stage 4. Glaciofluvial sands were deposited upon an erosional surface capping the Ulstrup lake sediments (all Rubjerg Knude Formation). Depositional base level was probably equivalent to that experienced in stage 8 in the adjacent Stensnæs Section (see above).

Ulstrup stage 5 . The final foreland thrusting took place as the UL01 thrust sheet was thrust over the upper ramp of the foreland and propagated about $200 \mathrm{~m}$ to the south. When the anticline above the UL02 hanging-wall ramp approached the footwall ramp of the foreland, where a fault-bend formed continuously during the propagation of the UL01 thrust sheet, a narrow channel was formed in which coarse-grained glaciofluvial gravel was deposited (Figs 27, 122). The gravel also included redeposited frozen blocks of sand, testifying to the ground-frozen conditions of the environment (Fig. 28).

Ulstrup stage 6. At the leading edge of the UL01 thrust fault, the deformation concluded with $150 \mathrm{~m}$ of displacement over the upper footwall flat of the foreland. During the translation of the UL01 thrust sheet over a minor depression in the foreland, a sandy mud volcano developed due to trapping of the high water pressure close to the leading-edge thrust. The sediment extrusion resulted in chaotic disturbances in the central part of UL01.

Ulstrup stage 7. The last stage of development in the Ulstrup Section involved sedimentation of the uppermost post-tectonic deposits of the Rubjerg Knude Formation. The conglomerate (of stage 5) was covered
Fig. 123. Summary scheme of the syntectonic sedimentary development in the Rubjerg Knude Glaciotectonic Complex. The deformation stages for each section, as described in the text, are indicated here by the symbol \#.

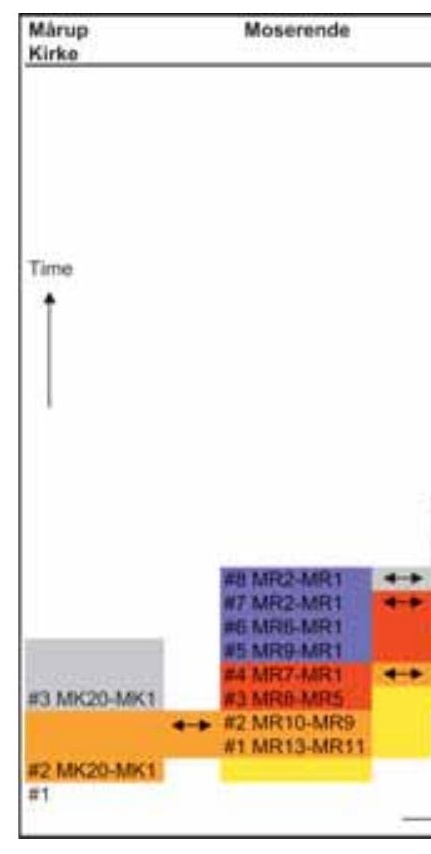

by sand, and deposition in the foreland covered the leading-edge thrust at Tvonnet Rende (for location see Plate 1).

$\begin{array}{ll}\text { Ulstrup Section:Summar y data } \\ \text { Balanced length }\left(\mathrm{L}_{0}\right): & \text { c. } 1350 \mathrm{~m} \\ \text { Cross-section length }\left(\mathrm{L}_{1}\right): & \text { c. } 850 \mathrm{~m} \\ \text { Shortening }(\Delta \mathrm{L}): & \text { c. } 500 \mathrm{~m} \\ \text { Compression: } & \text { c. } 37 \%\end{array}$

\section{Summary of dynamic development}

The dynamic development of the complex is summarised in Figs 123 and 124. From the scheme in Fig. 123, it is clear that the Rubjerg Knude Glaciotectonic Complex developed in sequential progressive stages during syntectonic sedimentation of the Rubjerg Knude Formation.

The thin-skinned thrust-fault complex developed mainly as piggyback thrusting with proximal thrust sheets being displaced contemporaneously with activation of the distal thrust fault. During the advance of the thrust-fault complex, the position of the décollement zone shifted progressively to deeper levels. The dynamic development can be summarised in eight steps that resulted in the formation of eight characteristic thrust-fault structure types (Fig. 124). 


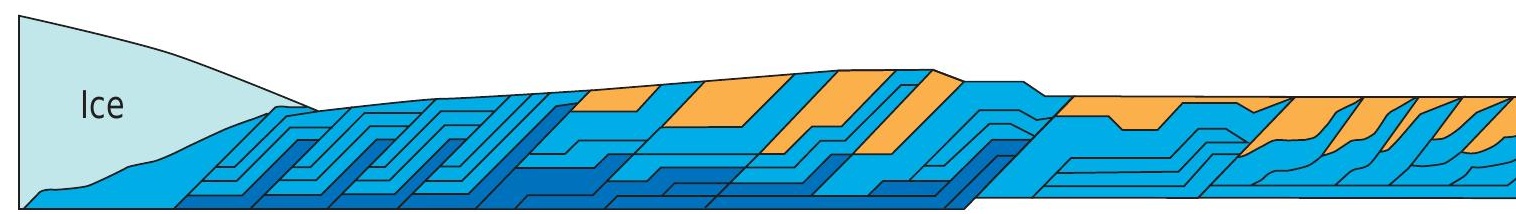

Fault-bend-folded duplex

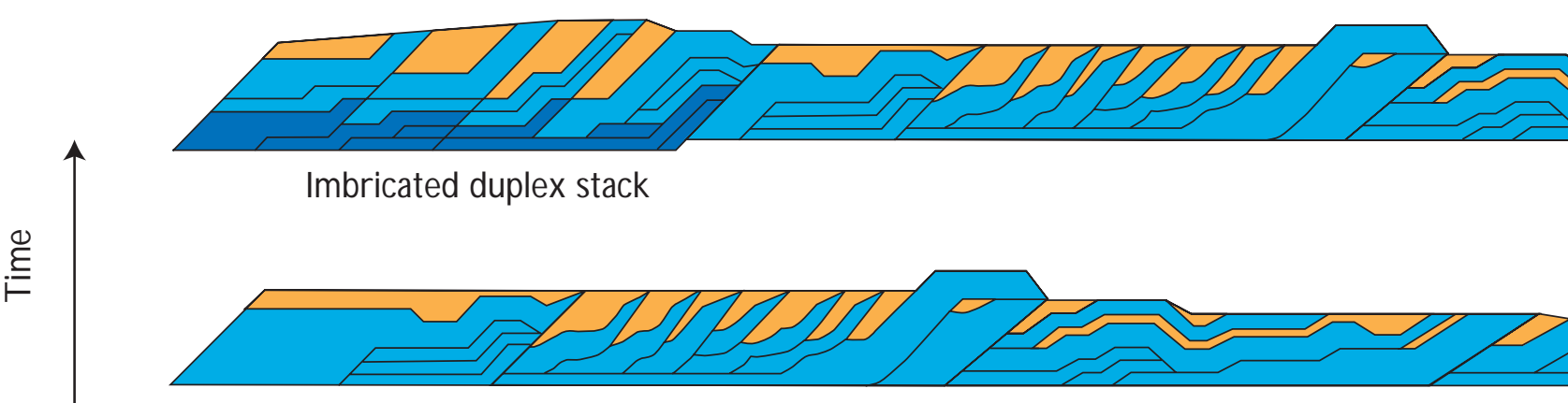

Duplex stack

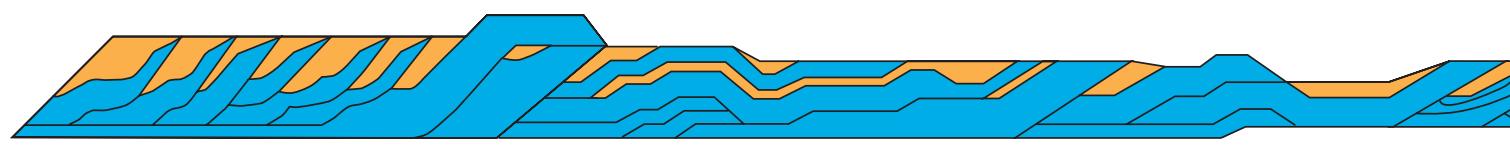

Imbricate fan

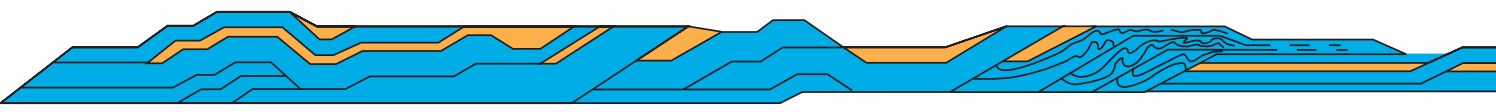

Antiformal stack

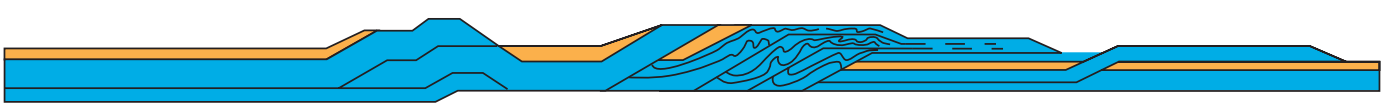

Hanging-wall anticline

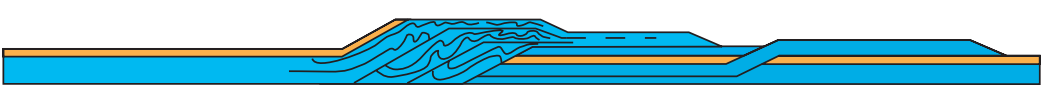

Duplex folds at ramp collapse

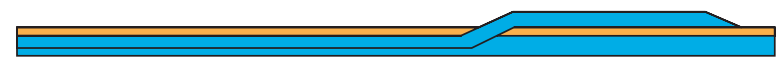

N

Foreland translated thrust sheet

\section{Distance}

Fig. 124. Model of thrust-fault structure types formed during the progressive deformation of the thin-skinned glaciotectonic thrust-fault complex. The model outlines a progressive development in eight steps resulting in the formation of eight characteristic thrust-fault structure types, the first to develop earliest and continuously in the distal part of the complex, and the last to be formed in the most proximal part of the complex (see text for details). 

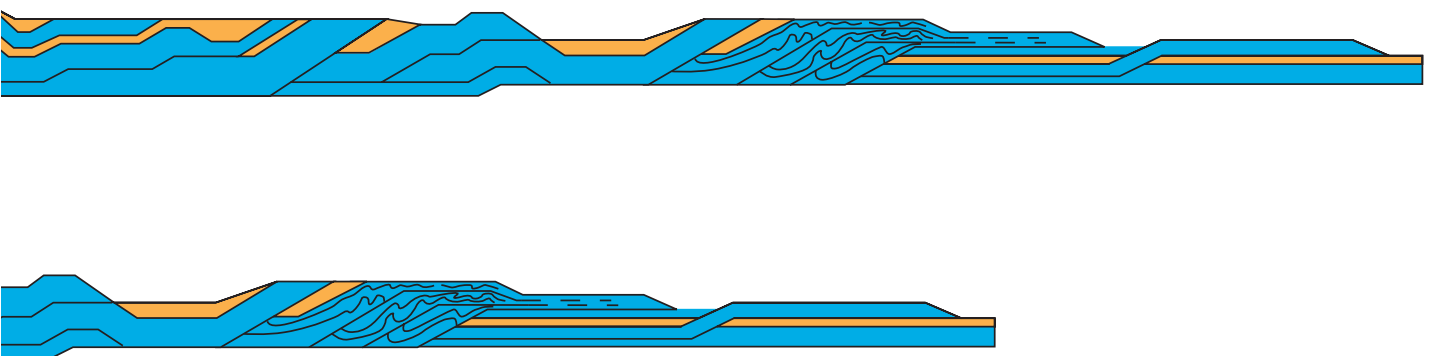

Rubjerg Knude Formation

Lønstrup Klint Formation

Stortorn Formation 


\section{Discussion}

The observations that form the basis for the description of the structural geology, mechanical behaviour and dynamic development of the Rubjerg Knude Glaciotectonic Complex, raise important questions with respect to understanding the framework and nature of thin-skinned thrusting related to glacial deformation; seven topics have been selected for further discussion below. The basis for understanding a structural complex is to describe the tectonic architecture and the range of structures it contains from microscopic to macroscopic scale. The discussion of thrust-faultarchitecture leads to evaluation of the reliability of the balanced cross-section. Consideration of thrust brecciation and diapirism leads naturally to a focus on the thrustfault dynamics, and the significance of the rate of deformation. The dynamics associated with the syntectonic deposits and the formation of piggyback basins merit discussion, as does the interpretation of a proglacial contra subglacial deformational setting. The final topic deals with the geological setting of the complex, including the timing of the event that created it.

\section{Thrust-fault architecture}

A prerequisite for understanding the thrust-fault architecture is a familiarity with the terminology (see Appendix 2). The macroscopic structures encountered in thin-skinned orogenic beltsareall recognisable in the glaciotectonic complex. Mesoscopic structures such as folds and faults are similarly recognisable. However, small-scale structures such as joints, cleavage and fabric are more difficult to recognise (except for hydrodynamic brecciation), and this may be one of the major differences between soft sedimentary deformation and hard-rock deformation.

It seems likely that joints and fractures in soft sediments would be able to re-heal after deformation. Thus, a large number of minor reverse faults must have formed in thrust sheets during ramp propagation (Fig. 67), but appear to have disappeared again after subsequent thrust sheet propagation along the flat, as they havenotbeen observed with the exception of the in situ positions related to ramp bend (Fig. 85). There is an approximation to a right-angle relationship between the footwall ramp and the back-thrust faults, which indicates that an increase in the dip of the footwall ramp results in a decrease in the dip, in the opposite direction, of the back thrust. Moreover, a steeper and higher footwall ramp also corresponds to an increase in displacement along the back-thrust fault. Thus one can regard the KR01 (Kramrende) back-thrust faults as structures related to initial faulting in the progressive deformation (Fig. 67), and the KR04 back-thrust splay faults as a structural element related to a developed phase of progressive thrust-fault deformation (Fig. 72). Major back thrusting at the back of SR02 (Fig. 84) represents a mature phase in the progressive thrust faulting. The apparent lack of joints and fractures reflecting ramp propagation could probably be explained as having been absorbed in the hydrodynamic brecciation process.

Among the structural elements analysed during the interpretation of the balanced cross-section, the duplex structures create the most interesting problems. Firstly, the interpretation of the duplex imbricates in the Stensnæs Section provides an explanation for the complicated fold framework. Secondly, the interpretation of the duplex below the frontal part of the Stortorn Section links the hidden duplex segments at the base of the Grønne Rende Section with the duplex stacking below ST01-ST03. Thirdly, the normal faults can be interpreted to have been related to the ramping of lower duplex segments. If the normal faults are regarded as foreland-dipping faults or part of a foreland-dipping duplex, the model for duplex formation suggested by Contreras \& Sutter (1997) may be relevant for the understanding of the foreland-dipping faults. In their model for formation of foreland- or hinterland-dipping duplexes, they considered two factors: $\mathrm{u}=$ distance of displacement along the upper flat, and $s=$ length of duplex segment. In a regime where the ratio $\mathrm{u} / \mathrm{s}$ is greater than one $(\mathrm{u} / \mathrm{s}>1)$, foreland-dipping duplexes are formed; in a regime where $\mathrm{u} / \mathrm{s}<1 / 2$, hinterland-dipping duplexes are formed. In regimes where $1 / 2<\mathrm{u} / \mathrm{s}<1$ or $\mathrm{u} / \mathrm{s}=1$, antiformal stacks or angular antiformal stacks, respectively, are formed. This corresponds well to the interpretation presented here of the Rubjerg Knude cross-section, where most thrust sheets are displaced by less than their length, and consequently the main orientation of thrust sheets is hinterland dipping. According to the model of Contreras \& Sutter (1997), foreland-dip- 
ping duplexes are formed when a duplex segment is displaced along an intermediate or upper flat for a distance equal to, or more than, its length. A consequence of this is that a roofing thrust sheet will be displaced in front of the foreland-dipping upper footwall flat, where nomal faulting will take place. This is interpreted to be the case for the normal faults in the Martørv Bakker and Brede Rende Sections (see Fig. 66). The normal fault developed in the Stenstue Rende Section may also be regarded as an expression of the latter regime in the suggested model. A foreland-dipping feature may well reflect the foreland-dipping limb of a hanging-wall anticline formed above a laterally displaced hanging-wall ramp. However, the normal fault-displaced thrust sheet must be thrust over the duplex segmentbefore it was thrust faulted together with its roofing thrust sheet, and then as translation continued attached to the hanging-wall flat until the displacement was concluded by the normal faulting over the tip of the duplex segment.

The consideration of duplex formation naturally leads to a focus on the changes in décollement levels. When a duplex segment is formed, there would normally be an early décollement surface at a shallow level, succeeded by a shift to a deeper level connected with a new footwall ramp. The upper décollement level (the $10 \mathrm{~m}$ level or corresponding gently dipping ramp to the leading edge) was probably the first to be formed in the proximal part of the complex and probably also the last to form in the distal part (Fig. 124). From the cross-section, it is indicated that the $10 \mathrm{~m}$ décollement level extended for about $1 \mathrm{~km}$, but ended up with a distance of only $600 \mathrm{~m}$. The $20 \mathrm{~m}$ décollement level was the next to take over, and during the establishment of a related ramp, footwall ramp imbrication progressed, modifying the ramp transition connecting the two décollement levels. The length of this décollement level might have been of the same scale, but only c. $400 \mathrm{~m}$ is preserved as a lower footwall flat. The $30 \mathrm{~m}$ flat level is the dominant décollement level extending from the middle of the Martørv Bakker Section to the middle part of the Stortorn Section, where finally the $40 \mathrm{~m}$ décollement level was developed. Note that the present-day position of the lowermost décollement surface is at about $45 \mathrm{~m}$ b.s.l. due to the regional, very gentle dip to the north of the L/R-unconformity that serves as the reference level, corresponding to the $0 \mathrm{~m}$ flat level. From the cross-section, it can be seen that the dips of the ramps increase from gentle $\left(5-15^{\circ}\right)$ in the zone between the upper surface flat to the $10 \mathrm{~m}$ flat level, to $25^{\circ}$ dips between the 10 and $20 \mathrm{~m}$ levels, and reaching up to $35^{\circ}$ between the 20 and $30 \mathrm{~m}$ flat levels. The ramp dips with steeper angles in the cross-section, arise from over-steepening or superimposed tilting during ramp propagation (Fig. 9). Thus, in the proximal part of the complex, dips between $35^{\circ}$ and $45^{\circ}$ are interpreted as the primary dips of ramps rooting down to the deepest décollement level at $40 \mathrm{~m}$, which is incorporated in the model for the fold-imbricate duplex units. The increasing dips of ramps are interpreted to have resulted from the increase in fracture angle as a function of increase in normal stress (change of levels) and increase in shear stress (increasing force required to move thrust sheets). This is implied from the shape of the Mohrenvelope in the Mohr diagram (Hobbs et al. 1976), and itissuggested to be a basic relationship for glaciotectonic fracture and faultdeformation(Pedersen 1996).

\section{Balanced cross-section}

In the balanced cross-section, the changes in dip angles are responsible for the insertion of a number of small triangular-shaped duplex segments, which are incorporated in the geometric construction and annotated as splints (horses) (Plate 2). It is not known how many splints exist in reality. A few have been recognised as structural identities (KR01 ${ }_{\mathrm{S}}$ in Kramrende), but it is likely that space deficits or excesses have been absorbed in mud-mobilisation or differential small-scale anastomosing fracturing. Differential fracturing and thrust-fault formation with a spacing of only $1 \mathrm{~m}$ has been documented in the Moserende Section (Fig. 27), indicating that the duplex segmentation does exist. Hence it is probable that a much more differential translation to ok place than is indicated in the crosssections of the dynamic model of thrust-fault propagation (Fig. 112).

The reliability of the approximations in construction inherent in a balanced cross-section is founded in the area balance. The main calculation of the balance indicates that the shortening amounts to approximately $50 \%$, with $\mathrm{L}_{0}=12 \mathrm{~km}$ and $\mathrm{L}_{1}=6 \mathrm{~km}$. The area of the $\mathrm{L}_{0}$ cross-section ( $\mathrm{L}_{0}$ multiplied by stratigraphic thickness) amounts to $340000 \mathrm{~m}^{2}$, and the area of the $\mathrm{L}_{1}$ cross-section ( $\mathrm{L}_{1}$ multiplied by measured thickness of the retrodeformed cross-section) is $382500 \mathrm{~m}^{2}$. The difference amounts to $11 \%$, which is interpreted as a consequence of the erosion of the thrust sheets in the proximal part of the complex (Grønne Rende Section - Ribjerg Section). The detailed calculations of areas 
for the area balance are summarised in Table 1, and documented in Plates 2A and 2B. The amount of erosion indicated from the area balance differs markedly from the 80\% erosion estimate by Gry (1941), and supports the argument that Gry's cylindrical thrust-fault model was incorrect.

Considering the amount of erosion, the question arises: why is the preservation potential so great? Three factors are suggested here to answer this: (1) the steeply orientated thrust sheets were partly packed by the sand fill in the piggyback basins, (2) the thrust-fault deformation resulted in a strain hardening that consolidated the complex, and (3) as the sole of the approaching ice sheet advanced across the proximal part of the complex, the over-pressured pore water migrated from the hanging-wall ramps and flats of the thrust sheets to the hanging-wall flat of the ice sheet, facilitating the over-thrusting of the footwall block which subsequently comprised the thrust-fault complex.

\section{Thrust brecciation and diapirism}

In order for a thrust sheet to move, a fracture must be created that can develop into a plane of thrusting. The initial fracture is fomed when the failure limit is reached in a system subjected to pressure (loading and lateral compression). A recurring question, and an apparent conflict in reasoning, is why fault planes develop, leaving the rest of the thrust sheet preserved? Since the sedimentary unit forming a thrust sheet is subjected to the same amount of confining pressure, it might be expected that a muddy mass of collapsed sedimentary units just as well could have been the result?

It is well known that an increase in pore-water pressure results in failure and initialisation of fractures along surfaces of anisotropy, as described for orogenic systems by Hubbert \& Rubey (1959). However, in soft sedimentary deformation with lower confining pressure and smaller shear strength, as well as smaller coefficient of internal friction, the limits of fracture formation and complete collapse are much narrower. The structures developed in the Ulstrup Section reflect these conditions. The anastomosing jointing and mud mobilisation at the tip of the UL01 thrust sheet reflect the stage of near collapse (Fig. 49). The thick zone of hydrodynamic brecciation along the hangingwall flat reflects the same tendency towards collapse, and speculations about the influence of ground-frozen conditions on the preservation of the thin thrust sheets during translation over the foreland are relevant. Ground-frozen conditions are interpreted to have affected that part of the thrust sheets elevated above the ground surface; the freezing of the sediments in the thrust sheet may result in more brittle behaviour, whereby cracks formed (Figs 44, 46). However, due to the high pore pressure maintained along the hanging-wall flat, the cracks were filled with sand pumped into the cracks by the over-pressured pore water from the base of the thrust sheet.

Hydrodynamic brecciation is evidently related to the hanging-wall ramp-and-flat. Brecciation was initiated at an episedimentary stage with the formation of ball-and-pillow structures due to sediment loading. When the loading increased by over-thrusting, the ball-and-pillow formation progressed further and hydrodynamic brecciation was concentrated at the hanging-wallflat. Small-scale mud diapirism took place, with chaotic folding developing into polydiapirs (Figs $54,55,77,78,86,88)$. Polydiapirism and mud-mobilisation are considered to have developed simultaneously and with an increasing degree of disordering and size of diapir in progressive stages of deformation. Many of the mesoscopic diapir structures recognised in the Rubjerg Knude Glaciotectonic Complex can be compared with the multi-wavelength gravity structures described in the model analysis by Weinberg \& Schmeling (1992). The formation of large-scale diapirs is suggested to have been related to thrustfault deformation of a deep-seated hanging-wall flat that propagated up to surface level along a set of relatively steep footwall ramps. During propagation up along a lower ramp to an intemediate flat, and ramping from the $20 \mathrm{~m}$ intermediate flat level to the $10 \mathrm{~m}$ flat level, polysequential hanging-wall anticlines formed, and were subsequently destroyed by mudmobilisation initiated from the deep-seated thrust zone of the hanging-wall flat. Some of the soft sedimentary xenoliths floating in the mud diapirs can be viewed as relicts of anticline crests (Fig. 74). Staircase-like ramp propagation is indicated for the Kramrende diapir and the Sandrende diapir, but is not so obvious in the case of the Brede Rende diapir. Intrusive remobilised mud is evidently related to the footwall ramp propagated hanging-wall flat of GR01, and the mud mobilisation in the thrust sheets of the Stortorn and Moserende Sections are all easily identified with sequential ramping from the deepest décollement level. 


\section{Thrust-fault dynamics}

The difference in thrust-fault development that relates to the upper flat level $(10 \mathrm{~m})$ is very marked when the Ulstrup Section is compared to the Grønne Rende Section. Thus the foreland regime in the latest stage of deformation is characterised by thin, very long sheets subjected to horizontal translation over the footwall flat of the foreland. In contrast, the Grønne Rende Section probably fomed an imbricate complex of smaller, moderately dipping thrust sheets when this section was adjacent to the foreland. There is no obvious reason for this difference, although minor differences in lithology and differences in environmental conditions (frozen or unfrozen ground) could be viewed as contributing factors. However, there is an invisible condition which must be considered, namely the velocity of deformation. At the initiation of any deformation, the velocity is zero; the velocity then increases until the displacement is brought to a halt at the edge of the foreland during decreasing velocity. Fast deformation results in more fractures than slow deformation. It is therefore suggested that the imbricate structures in the central part of the thrust-fault complex were initiated during the fastest advance towards the foreland and that the long-distance translation of unbroken thrust sheets relates to decreasing velocity or slow advance.

In a discussion of the velocity of thrust-fault propagation, the question of rates and timing is inevitable. Theyoungest dating of the Stortorn Formation is 30000 years B.P., while the oldest dating of the Rubjerg Knude Formation is about 29000 years B.P. and the oldest dating of the Ribjerg Formation is 26000 years B.P. Thus, a time span of 3000 years is estimated for the calculated shortening of $6 \mathrm{~km}$, which indicates an average velocity of $2 \mathrm{~m}$ per year.

The peak velocity of the deformation must evidently have been more than $2 \mathrm{~m}$ per year, taking into account the acceleration and deceleration. However, the velocity would also have been much higher if deformation had progressed in periodic steps rather than continuously. A step-like process would have involved periods of no movement alternating with higher velocity in the periods of advance. With respect to the Rubjerg Knude Glaciotectonic Complex, the summary of the dynamic development suggests that a continuous progressive deformation process characterised the formation of the complex (Fig. 123). Although the developments of the sections are described separately above, the deformational overlap from one section to thenextlinks the sections in a continuous dynamic development.

\section{Syntectonic deposition}

The concept of piggyback basins was originally related to large-scale regionalorogenic settings (Ori \& Friend 1984; Ricci Lucchi 1986). However, as applied here the term is used for the syntectonic deposits of the Rubjerg Knude Formation that were laid down in basins structurally overlying moving thrust sheets. The initial depositional environment of the Rubjerg Knude Formation was a relatively flat lowland, dominated by shallow lakes in an outwash plain bounded by an ice margin to the north. The plain was probably gently dipping towards the north due to isostatic loading of the ice cap. Judging from the variation in thickness of the Rubjerg Knude Formation (30 $\mathrm{m}$ in the proximal part to only about $10 \mathrm{~m}$ in the distal), the dip of the plain was not more than $2^{\circ}$.

As the thrust belt propagated southwards, the plain became separated into smaller, more or less isolated basins characterised by steep slopes and uneven relief. The most distinctive deposits in these basins are the sedimentary breccias and slumped thrust sheets derived from the tips of up-thrust thrust sheets.

Three types of syntectonic slump/slide deposits can be differentiated. The first type involves deposition of coarse clasts up to metre size, which were rotated indicating transport as sedimentary clasts enveloped by sandy mud. This deposit type is regarded as being related to the distal part of the thrust-fault system, and is exemplified by the piggyback basin in the Stensnæs Section (Fig. 56). The second type is characterised by isoclinally folded slump sheets interlayered with matrix-supported coarse clastic diamictite. This indicates that the source was very close to the depocentre, although the slump sheets were detached from their roots and were transported independently by gravity gliding into the basin. The piggyback basin in the Martørv Bakker Section represents this deposit type (Figs 23, 64). The third type comprises slump-folded sheet segments that can be traced directly, or correlated over short distances, back to the source of the thrust sheet; this type is regarded as being related to the proximal part of the system. The next step in the development would be that of thrust sheets displaced by normal faulting, but lacking depositional features such as sedimentary breccias. However, this type of dynamic development is strictly tectonic. The major 
slump fold occurring in the Stenstue Rende Section (Fig. 89) may be regarded as a transition from a sedimentary to a tectonic regime. The deposition of recognisable thrust-sheet tips in the piggyback basins supports the concept of a continuous thrust-fault process.

\section{Proglacial and subglacial deformation}

Glaciotectonic analyses distinguish between deformation generated in proglacial and in subglacial regimes (Aber 1982; Croot 1988; Aber etal. 1989; Pedersen 1993, 1996, 2000). It has already been argued that the thinskinned thrust-fault deformation of the Rubjerg Knude Glaciotectonic Complex is an example of proglacial deformation. Thekey evidence for this is the presence of intimately associated syntectonic piggyback basins. These basins must have been situated in front of the ice margin, with sedimentation taking place under open water, simultaneously with thrust-fault propagation.

However, the subglacial deformation is represented locally by the $1 \mathrm{~m}$ thick glacitectonite occurring below the glaciotectonic unconformity that truncated the thrust-fault complex. This is found in the glaciolacustrine beds at the top of the UL02 thrust sheet in the northern part of the Ulstrup Section. It can be argued that here the subglacial defomation penetrated down a depth of c. $5 \mathrm{~m}$ below the glaciotectonic unconformity. Mud diapirism and hydrodynamic brecciation occurred in this setting, probably caused by loading when the ice sheet overrode the sediments. The focus of subglacial deformation is at the Blå-unconformity (Fig. 32). In the northernmost $300 \mathrm{~m}$ of the cross-section, the effects of mud mobilisation increase to a point at which primary sedimentary as well as early structural features are completely destroyed. This phase of deformation is interpreted to have taken place while the sole of the frontal part of the ice sheet was fixed to the trailing end of the thrust-fault complex. This also implies that the velocity of the thrust faulting was equal to the advance of the ice sheet. The advance of the ice-sheet load corresponds to the mechanics of gravity spreading (Pedersen 1987). The increasing propagating stress resulted in increasing mud mobilisation, and subsequently the overpressure was transmitted laterally by the mud fluid towards the foreland. The mechanism might well be compared to squeezing toothpaste out of its tube.

At a certain stage, the fluid pressure was released, probably due to migration of all the hydrodynamic breccias, and the mobilised mud consolidated. Sub- sequent to consolidation, the frontal sole of the icesheet released contact with the Blå-unconformity and propagated over the thrust-fault complex formed in the foreland of the ice margin. During this process, subglacial shearing affected the top of the structureless consolidated mud, and anastomosing as well as plane-parallel shear fractures were formed (Fig. 32).

In soft sediment structural geology, the gravityspreading model has been successfully applied to the geological setting of the mud lumps in the Mississippi Delta (Morgan et al. 1968; Pedersen 1987; Aber et al. 1989). It could therefore be suggested that a gravityspreading model due to clastic progradation might be the deformation mechanism. However, there is no known delta setting at this time/place that could have provided the basis for this model, and furthermore, the sand units observed here only reach a third of the thickness of the $100 \mathrm{~m}$ delta-sand units in the Mississippi Delta setting. Finally, the presence of the glaciotectonic unconformity and related glacitectonite is incompatible with a sand sediment-spreading process.

Although a delta setting has not been documented, it might be suggested that a slope similar to that of a megascopic delta foreset existed, and that the deformation was caused by major gravity gliding on this slope, or was simply due to uplift in the hinterland. However, this is not considered likely. The isostatic rebound documented from the elevation of the Vendsyssel Formation reaches $60 \mathrm{~m}$ a.s.l. To this must be added the uplift due to the lowering of sea level; the area in the hinterland was thus an area of subsidence rather than uplift. Structurally, a gravity-gliding model would provide extensional normal fault systems in the trailing end of the thrust-fault complex (Pedersen 1987). This is not compatible with the observed increase in compressional structures in the hinterland, as documented in the cross-section and indicated by the balanced cross-section; a gravity-gliding model for the complex can therefore be rejected.

Such larger glaciotectonic complexes are often so impressive that some geologists suggest that they were formed by orogenic activity (Lykke-Andersen 1992; K. Binzer, personal communication 1997). Disregarding the obvious glacial geological indications, there are two features that distinguish glaciotectonic complexes from basement-involved deformation: (1) the superficial detachment, and (2) the rate of translation. In the Rubjerg Knude Glaciotectonic Complex, there are no infracrustal rocks involved and the thrust sheets are not rooted down into a deep-seated hinterland source. The lowermost detachment level is $40 \mathrm{~m}$ be- 
low the reference level, which is more or less coincident with present sea level, and there are no indications that the deformation extended below the $40 \mathrm{~m}$ level. The velocity of thrust-sheet motion in orogenic mountain ranges is of the order of $1 \mathrm{~cm}$ per year (Wiltscko \& Dorr 1983). In glaciotectonic systems, the velocity can be up to 100 times as fast, as documented by the velocity estimate of $2 \mathrm{~m}$ per year for the $\mathrm{Ru}$ bjerg Knude Glaciotectonic Complex.

\section{Glacial geological conditions}

The Rubjerg Knude Glaciotectonic Complex is interpreted to have formed due to the advance of the Norwegian Ice in the late Middle Weichselian. The Norwegian Ice melted back at the beginning of Late Weichselian time and was succeeded by a renewed advance of the Scandinavian Ice Sheet from central Sweden. In that part of Denmark east and north of the Main Stationary Line (Figs 1, 12), the direction of this advance was towards the south-west and the advance is thus referred to as the NE-Ice (Houmark-Nielsen 1987). The eastward advance of this ice towards Vendsyssel probably formed the N-S-trending hilly landscape named Jyske Ås, the formation of which was contemporaneous with deposition of the outwash plain represented by the Ribjerg Formation. When the NE-Ice advance reached the Rubjerg Knude Glaciotectonic Complex, it only resulted in minor superimposed deformation. The oblique orientation of the fold axis of the megaslump in the Stenstue Rende Section might be due to such superimposed deformation, but in general very few glaciotectonic disturbances can be related to the NE-Ice advance. That overriding by the NE-Ice had so little effect may be attributed to strain hardening due to the preceding deformation, or the smoothing out of the landscape by the former glaciotectonic unconformity, which would facilitate the second overriding of the complex. Ground-frozen conditions could also have been a factor, since this would have prevented drainage from the ice sheet through the substratum, resulting in high pore-water pressures at the sole of the ice. The effect of this would have been to facilitate easy and fast propagation over the complex, although it by then formed a hill in the landscape.

The Norwegian Ice produced a hill-and-hole pair with Rubjerg Knude as the hill and the depression extending from Lønstrup northwards as the hole. Immediately after the melting back of the NE-Ice, the landscape was covered by the Vendsyssel Formation. A contour map of the base of the Vendsyssel Formation (Fig. 125) thus provides a picture of the geomorphology of the young glacial landscape unaffected by the succeeding 15000 years of erosion. In Fig. 125, the hill-and-hole pair is readily identified and the general E-W morphological trends are well represented. To the east, this trend is truncated by a strong SE-NW hill-and-hole geomorphology, related to the NE-Ice. The trend of the thrust-fault belt of the Rubjerg Knude Glaciotectonic Complex can be followed from the coastline to the east for about $2.5-5 \mathrm{~km}$. The eastern fringe of the complex has been eroded down to sea level, probably by the NE-Ice, and subsequently concealed by the Vendsyssel Formation. 


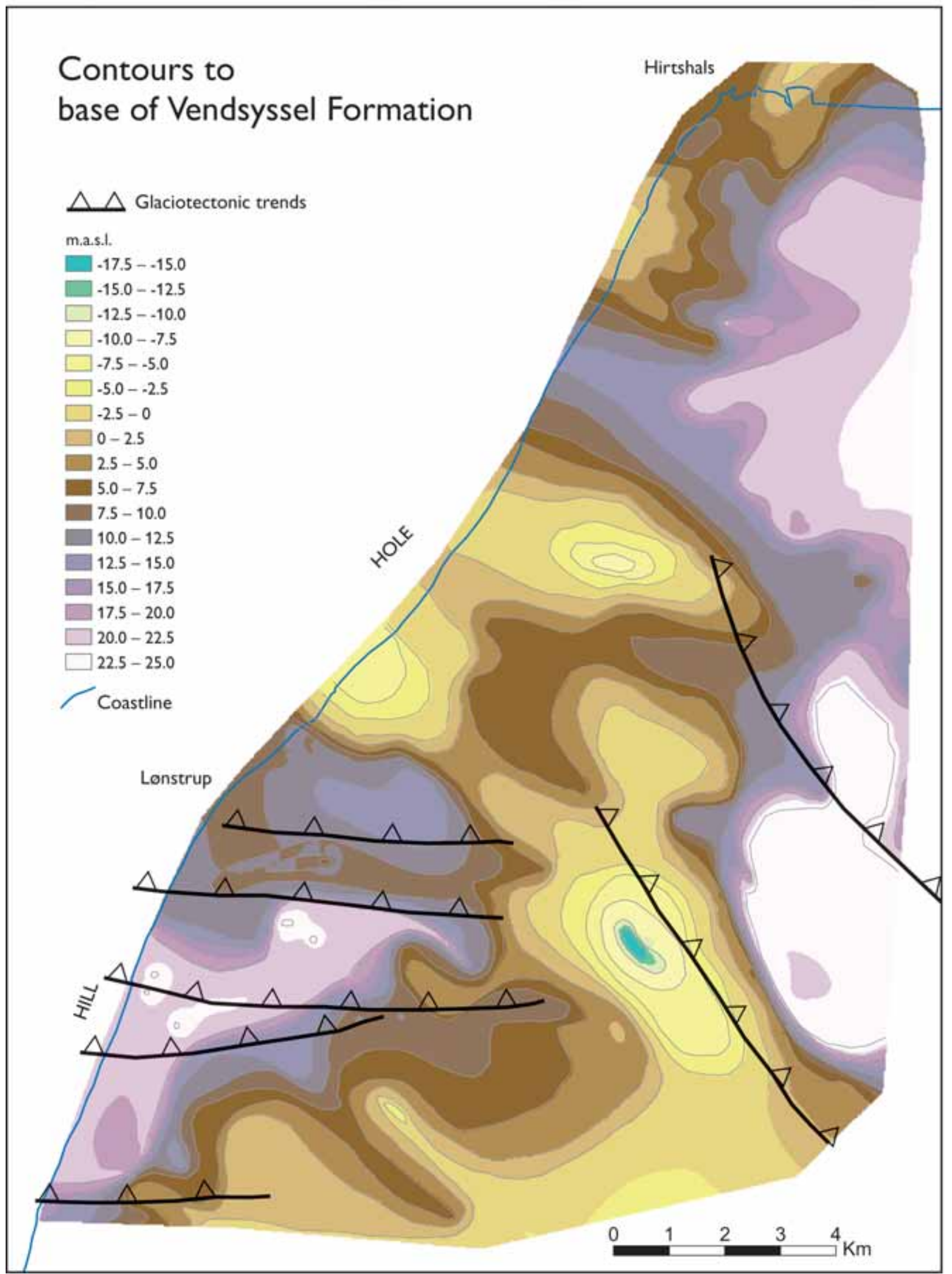




\section{Conclusions}

Structural analysis of the Rubjerg Knude Glaciotectonic Complex, based on detailed photogrammetric measurements and field investigations, provides a geological cross-section through a low-friction thrustfault system. Interpretation of the entire thrust-fault architecture included unexposed parts of the complex, and is based on the construction of a balanced crosssection. A model for the dynamic development demonstrates that deformation progressed continuously and involved formation of duplexes and mud diapirs. Although the thrust-fault structures were formed in a proglacial regime related to the advance of the Norwegian Ice (30 000 - 26000 B.P.), the structures can be viewed as representing an almost complete model of thin-skinned thrust-fault systems.

For descriptive purposes, the complex is subdivided into 13 sections, which demonstrate the structural development from a proximal to a distal position in the thrust-fault system. Investigation of these sections provided the following main conclusions.

1. The structural elements in the Rubjerg Knude Glaciotectonic Complex comprise ramps and flats related to hanging-wall and footwall positions, respectively. Hanging-wall anticlines and footwall synclines were formed due to thrust-fault propagation. Back-thrust faults were formed during upper ramp-hinge propagation, and an irregular fold framework developed in relation to sequential duplex imbricate formation during footwall ramp collapse. Foreland-dipping normal faults were formed in relation to translation of duplex segments.

2. From the balanced cross-section, the shortening during thrust-fault deformation is calculated to have been c. $50 \%$. About $11 \%$ of the initial stratigraphic unit subjected to thrust faulting is estimated to have been lost due to erosion. The décollement zone was at its deepest position $(40 \mathrm{~m})$ in the proximal

\section{Facing page:}

Fig. 125. Contour map of the pre-Vendsyssel Formation landscape; for location, see Fig. 13. Note the depression north of Lønstrup which represents the hole in the hill-and-hole pair morphology of a glaciotectonic complex; the corresponding hill is represented by the high at Rubjerg Knude. The map isbased on data from theGEUS well database and from Plate 1. sections, becoming shallower towards the foreland. Stacking ofduplex segments is correlated with space problems created in the subsurface due to initial displacements at the upper levels. Stacking of duplex segments correlates well with the elevation of the reference level in the system.

3. Hydrodynamic brecciation was dominantly related to the hanging-wall ramps and flats. Polydiapirism and mud mobilisation characterise the thrust zones. Mud mobilisation resulted in the formation of larger mud diapirs, and preferentially evolved during hanging-wall propagation from the décollement level up above sets of intermediate and upper footwall ramps.

4. Syntectonic deposition took place in piggyback basins overlying the thrust sheets. Thrust sheets exposed to erosion provided sediment to the basins, and in some cases major lumps derived from the tips of thrust sheets slumped and slid as megablocks into the piggyback basins.

5. The thrust-fault deformation was caused by gravity spreading at the front of an advancing ice sheet. Over-pressured mud formed an important part of the stress transfer. The average velocity of the thrust-fault displacement is estimated to have been $2 \mathrm{~m}$ per year. A $40 \mathrm{~m}$ thick succession of flat-lying sediments, extending for $12 \mathrm{~km}$, was compressed into a thrust-sheet complex that was $6 \mathrm{~km}$ in length and up to $80 \mathrm{~m}$ thick.

\section{Acknowledgements}

The Geological Survey of Denmark and Greenland is thanked for supporting this project during the last 10 years. Initial investigations were carried out while the author held a senior stipend at the Geological Institute, University of Copenhagen. The Carlsberg Foundation supported the project with a one year research grant, which is gratefully acknowledged; the Danish Research Agency is thanked for financial support for printing this bulletin. Keld Dueholm and the Institute of Survey and Photogrammetry are thanked for their co-operation and willingness to provide time and fa- 
cilities at the photogrammetric instrument at the Technical University of Denmark.

Frants von Platen-Hallermund is thanked for assistance with the ARC-INFO transformation and ARC-VIEW editing, which provided the graphic display of Plates 1 and 2. Alice Rosenstand and Benny M. Schark helped in drafting the figures, and the staff of the Graphic
Section at GEUS are thanked for technical support.

I am indebted to A.K. Higgins for reading the first draft of this manuscript, to two anonymous referees and the editor, Jon R. Ineson, for their constructive and helpful comments on the manuscript, and to my wife, Gunver K. Pedersen, for support and inspiring discussions during the progress of this work.

\section{References}

Aaris-Sørensen, K. 1995: Palaeoecology of a Late Weichselian vertebrate fauna from Nørre Lyngby, Denmark. Boreas 24, 355-365.

Aaris-Sørensen, K. \& Petersen, K.S. 1984: A late Weichselian find of polar bear (Ursus maritimus Phipps) from Denmark and reflections on the paleoenvironment. Boreas 13, 29-33.

Aber, J.S. 1982: Model for glaciotectonism. Bulletin of the Geological Society of Denmark 30, 79-90.

Aber, J.S. (ed.) 1993: Glaciotectonics and mapping glacial deposits. Canadian Plains Proceedings 25(1), 310 pp. Canadian Plains Research Center, University of Regina, Canada.

Aber, J.S., Croot, D.G. \& Fenton, M.M. 1989: Glaciotectonic landforms and structures. In: Bentley, C.R. (ed.): Glaciology and Quaternary geology, 200 pp. Dordrecht: Kluwer Academic Publishers.

Abrahamsen, N. \& Readman, P.W. 1980: Geomagnetic variations recorded in older ( $>$ or $=23000$ B.P.) and younger Yoldia Clay (approximately 14000 B.P.) at Nørre Lyngby, Denmark. Geophysical Journal of the Royal Astronomical Society 62(2), 329-344.

Bahnson, H., Petersen, K.S., Konradi, P.B. \& Knudsen, K.L. 1974: Stratigraphy of Quaternary deposits in the Skærumhede II boring: lithology, molluscs and foraminifera. Danmarks Geologiske Undersøgelse Årbog 1973, 27-62.

Banham, P.H. 1977: Glacitectonites in till stratigraphy. Boreas 6, 101-105.

Banham, P.H. 1988: Thin-skinned glaciotectonic structures. In: Croot, D.G. (ed.): Glaciotectonics: forms and processes, 2125. Rotterdam: A.A. Balkema.

Bard, E., Arnold, M., Fairbanks, R.G. \& Hamelin, B. 1993: ${ }^{230}$ Th${ }^{234} \mathrm{U}$ and $14 \mathrm{C}$ ages obtained by mass spectrometry on corals. Radiocarbon 35, 191-199.

Bendsen, N. 1981: Rubjerg Knude Fyr fra 1899 til 1980. Vendsyssel nu og da 1981, 5, 6-21. Hjørring, Denmark: Vendsyssel Historiske Museum.

Bennett, M.R. 2001: The morphology, structural evolution and significance of push moraines. Earth-Science Reviews 53, 197236.

Berthelsen, A. 1973: Weichselian ice advance and drift succes- sions in Denmark. Bulletin of the Geological Institute, University of Uppsala, New Series 5, 21-29.

Berthelsen, A. 1975: Lærebog for den lille tektoniker, 202 pp. Copenhagen: Varv.

Berthelsen, A. 1978: The methodology of kineto-stratigraphy as applied to glacial geology. Bulletin of the Geological Society of Denmark 27, 25-38.

Berthelsen, A. 1979: Recumbent folds and boudinage structures formed by subglacial shear: an example of gravity tectonics. Geologie en Mijnbouw 58, 253-260.

Boulton, G.S. 1986: Push-moraines and glacier-contact fans in marine and terrestrial environments. Sedimentology 33, 677698.

Boulton, G.S. \& Hindmarsh, R.C.A. 1987: Sediment deformation beneath glaciers: rheology and geological consequences. Journal of Geophysical Research 92, 9059-9082.

Boyer, S.E. \& Elliott, D. 1982: Thrust systems. American Association of Petroleum Geologists Bulletin 66, 1196-1230.

Bucher, W.H. 1956: The role of gravity in orogenesis. Geological Society of America Bulletin 67, 1295-1318.

Cheel, R.J. \& Rust, B.R. 1986: A sequence of soft-sediment deformation (dewatering) structures in Late Quaternary subaqueous outwash near Ottawa, Canada. Sedimentary Geology 47, 77-93.

Contreras, J. \& Sutter, M. 1997: A kinematic model for the formation of duplex systems with a perfectly planar roof thrust. Journal of Structural Geology 19, 269-278.

Croot, D.G. 1987: Glaciotectonic structures: a mesoscale model of thin-skinned thrust sheets? Journal of Structural Geology $\mathbf{9}$, 797-808.

Croot, D.G. 1988 (ed.): Glaciotectonics: forms and processes, 212 pp. Rotterdam: A.A. Balkema.

Dahlström, C.D.A. 1969: Balanced cross sections. Canadian Journal of Earth Sciences 6, 743-757.

Dennis, J.G. 1972: Structural geology, 532 pp. New York: Ronald. Dreimanis, A. 1988: Tills: their genetic terminology and classification. In: Goldthwait, R.P. \& Matsch, C.L (eds): Genetic classification of glacigenic deposits, 17-84. Rotterdam: A.A. Balkema. 
Dueholm, K. 1992: Geologic photogrammetry using standard small-frame cameras. In: Dueholm, K. \& Pedersen, A.K. (eds): Geological analysis and mapping using multi-model photogrammetry. Rapport Grønlands Geologiske Undersøgelse 156, 7-17.

Ehlers, J. (ed.) 1983: Glacial deposits in North-West Europe, 470 pp. Rotterdam: A.A. Balkema.

Erickson, S.G. \& Jamison, W.R. 1995: Viscous-plastic finite-element models of fault-bend folds. Journal of Structural Geology 17, 561-573.

Fairbanks, R.G. 1989: A 17000 year glacio-eustatic sea level recond: influence of glacial melting rates on the Younger Dryas event and deep-ocean circulation. Nature 342, 637-642.

Fredericia, J. 1982: Geologisk basisdatakort, 1:50.000, map sheet 1318 I, Skagen. København: Danmarks Geologiske Undersøgelse.

Fredericia, J. 1983a: Geologisk basisdatakort, 1:50.000, map sheet 1217 I, Løkken. København: Danmarks Geologiske Undersøgelse.

Fredericia, J. 1983b: Geologisk basisdatakort, 1:50.000, map sheet 1318 III, Hjørring. København: Danmarks Geologiske Undersøgelse.

Fredericia, J. 1984: Geologisk basisdatakort, 1:50.000, map sheet 1317 I + IV, Brønderslev. København: Danmarks Geologiske Undersøgelse.

Goldthwait, R.P. \& Matsch, C.L. (eds) 1988: Genetic classification of glacigenic deposits, 294 pp. Rotterdam: A.A. Balkema.

Gripp, K. 1929: Glaziologische und geologische Ergebnisse der Hamburgischen Spitsbergen Expedition. Abhandlungen der Naturwissenschaftlichen Verein Hamburg 22, 147-247.

Gry, H. 1940: De istektoniske Fohold i Moleret. Med Bemærkninger om vore dislocerede Klinters Dannelse og om den negative Askeserie. Meddelelser fra Dansk Geologisk Forening 9, 586-627.

Gry, H. 1941: Diskussion om vore dislocerede Klinters Dannelse. Meddelelser fra Dansk Geologisk Forening 10, 39-51.

Hart, J.K. 1990: Proglacial glaciotectonic deformation and the origin of the Cromer Ridge push moraine complex, North Norfolk, England. Boreas 19, 165-180.

Hart, J.K. \& Watts, R.J. 1997: Comparison of the styles of deformation associated with two recent push moraines, south Van Keulenfjorden, Svalbard. Earth Surface Processes and Landforms 22, 1089-1107.

Hobbs, B.E., Means, W.D. \& Williams, P.F. 1976: An outline of structural geology, 571 pp. New York: John Wiley \& Sons, Inc.

Houmark-Nielsen, M. 1987: Pleistocene stratigraphy and glacial history of the central part of Denmark. Bulletin of the Geological Society of Denmark 36, 189 pp.

Houmark-Nielsen, M. 1988: Glaciotectonic unconformities in Pleistocene stratigraphy as evidence for the behaviour of former Scandinavian icesheets. In: Croot, D.G. (ed.): Glaciotectonics: forms and processes, 91-99. Rotterdam: A.A. Balkema.

Houmark-Nielsen, M. 1999: A lithostratigraphy of Weichselian glacial and interstadial deposits in Denmark. Bulletin of the Geological Society of Denmark 46, 101-114.
Houmark-Nielsen, M. 2003: Signature and timing of the Kattegat Ice Stream: onset of the Last Glacial Maximum sequence at the southwestern margin of the Scandinavian Ice Sheet. Boreas 32, 227-241.

Houmark-Nielsen, M., Bennike, O. \& Björck, S. 1996: Terrestrial biotas and environmental changes during the Late Middle Weichselian in North Jutland, Denmark. Bulletin of the Geological Society of Denmark 43, 169-176.

Hubbert, M.K. \& Rubey, W.W. 1959: Role of fluid pressure in mechanics of overthrust faulting. Geological Society of America Bulletin 70, 115-166.

Jaeger, J.C. \& Cook, N. 1979: Fundamentals of rock mechanics, 585 pp. London: Chapman \& Hall.

Jakobsen, P.R. 1996: Distribution and intensity of glaciotectonic deformation in Denmark. Bulletin of the Geological Society of Denmark 42, 175-185.

Jamison, W.R. 1987: Geometric analysis of fold development in overthrust terranes. Journal of Structural Geology 9, 207-319.

Jessen, A. 1899: Beskrivelse til geologisk Kort over Danmark i Maalestok 1:100.000. Kortbladene Skagen, Hirshals, Frederikshavn, Hjørring og Løkken. Danmarks Geologiske Undersøgelse 1. Række 3, 368 pp. +5 maps.

Jessen, A. 1918: Vendsyssels Geologi. Danmarks Geologiske Undersøgelse V. Række 2, 260 pp. + atlas.

Jessen, A. 1931: Lønstrup Klint. Danmarks Geologiske Undersøgelse II. Række 49, 142 pp. + atlas (with summary in English).

Jessen, A. \& Nordmann, V. 1915: Ferskvandslagene ved Nørre Lyngby. Danmarks Geologiske Undersøgelse II. Række 29, $66 \mathrm{pp}$.

Jessen, A., Milthers, V., Nordmann, V., Hartz, N. \& Hesselbo, A. 1910: En Boring gennem de kvartære Lag ved Skærumhede. Danmarks Geologiske Undersøgelse II. Række 25, 175 pp. + atlas.

Johnstrup, F. 1874: Über die Lagerungsverhältnisse und die Hebungs-Phänomene in den Kreidefelsen auf Mön und Rügen. Zeitschrift der deutsche geologische Gesellschaft 1874, 533585.

Johnstrup, F. 1882: Om de geologiske Forhold i den nordlige Del af Vendsyssel. Indbydelsesskrift til Universitetets Aarsfest til Erindring om Kirkens Reformation, 43 pp. + 1 plate (map). Kjøbenhavn.

Kitagawa, H. \& van der Plicht, J. 1998: Atmospheric radiocarbon calibration to $45.000 \mathrm{yr}$ BP: late glacial fluctuations and cosmogenic isotope production. Science 279, 1187-1189.

Klint, K.E.S. \& Pedersen, S.A.S. 1995: The Hanklit thrust fault complex, Mors, Denmark. Danmarks Geologiske Undersøgelse Serie A 35, $32 \mathrm{pp}$.

Knudsen, K.L 1978: Middle and Late Weichselian marine deposits at Nørre Lyngby, northern Jutland, Denmark. Danmarks Geologiske Undersøgelse II. Række 112, 44 pp.

Knudsen, K.L 1994: The marine Quaternary in Denmark: a review of new evidence from glacial-interglacial studies. Bulletin of the Geological Society of Denmark 41, 203-218.

Knudsen, K.L. \& Lykke-Andersen, A.L. 1982: Foraminifera in Late Saalian, Eemian, Early and Middle Weichselian of Skærumhede I boring. Bulletin of the Geological Society of Denmark 30, 97-109. 
Krog, H. \& Tauber, H. 1974: C-14 chronology of Late- and Postglacial marine deposits in North Jutland. Danmarks Geologiske Undersøgelse Årbog 1973, 93-105.

Larsen, E., Sejrup, H.P., Janocko, J., Landvik, J.Y., Stalsberg, K. \& Steinsund, P.I. 2000: Recurrent interaction between the Norwegian Channel Ice Stream and terrestrial-based ice across southwest Norway. Boreas 29, 185-203.

Larsen, G., Jørgensen, F.H. \& Prisholm, S. 1977: The stratigraphy, structure and origin of the glacial deposits in the Randers area, eastern Jutland. Danmarks Geologiske Undersøgelse II. Række 111, 36 pp.

Lykke-Andersen, A.-L. 1971: Foraminifera from the Older Yoldia Clay at Hirtshals. Bulletin of the Geological Society of Denmark 21(2-3), 159-184.

Lykke-Andersen, A.-L. 1987: A Late Saalian, Eemian and Weichselian marine sequence at Nøre Lyngby, Vendsyssel, Denmark. Boreas 16, 345-357.

Lykke-Andersen, A.-L \& Knudsen, K.L.1991: Saalian, Eemian and Weichselian in the Vendsyssel-Kattegat region, Denmark. In: Andersen, B.G. \& Köningsson, L-K. (eds): Late Quaternary stratigraphy in the Nordic countries 150000 - 15000 B.P. Striae 34, 135-140.

Lykke-Andersen, H. 1992: Massebevægelser i Vendsyssels og Kattegats kvartære aflejringer. Dansk Geologisk Forening Årsskrift 1990-91, 93-97.

Madsen, V. 1916: Ristinge Klint. Danmarks Geologiske Undersøgelse IV. Række 1(2), $32 \mathrm{pp.}$

Martinsen, O. 1994: Mass movements. In: Maltman, A. (ed.): The geological deformation of sediments, 127-165. London: Chapman \& Hall.

McClay, K.R. 1992: Glossary of thrust tectonics terms. In: McClay, K.R. (ed.): Thrust tectonics, 419-433. London: Chapman \& Hall.

Medwedeff, D.A. \& Suppe, J. 1997: Multibend fault-bend folding. Journal of Structural Geology 19, 279-292.

Mertz, E.L. 1924: Oversigt over de sen- og postglaciale Niveauforandringer i Danmark. Danmarks Geologiske Undersøgelse II. Række 41, 20 pp.

Milthers, V. 1909: Scandinavian indicator boulders in the Quaternary deposits. Danmarks Geologiske Undersøgelse II. Række 23, $153 \mathrm{pp}$.

Mitra, G. \& Sussman, A.J. 1997: Structural evolution of connecting splay duplexes and their implications for critical taper: an example based on geometry and kinematics of the Canyon Range culmination, Sevier Belt, central Utah. Journal of Structural Geology 19, 503-534.

Morgan, J.P., Coleman, J.M. \& Gagliano, S.M. 1968: Mudlumps: diapiric structures in Mississippi delta sediments. In: Braunstein, J. \& O'Brien, G.D. (eds): Diapirism and diapirs. American Association of Petroleum Geologists Memoir 8, 145-161.

Nielsen, L.H., Johannessen, P.N. \& Surlyk, F. 1988: A Late Pleistocene coarse-grained spit-platform sequence in northern Jylland, Denmark. Sedimentology 35, 915-937.

Nordmann, V. 1928: Marine Aflejringer. In: Madsen, V. (ed.): Oversigt over Danmarks Geologi. Danmarks Geologiske Undersøgelse V. Række 4, 95-99.

Oftedahl, C. 1981: Norges geologi, 171 pp. Trondheim: Tapir.
Ori, G.G. \& Friend, P.F. 1984: Sedimentary basins formed and carried piggyback on active thrust sheets. Geology 12, 475478.

Ozkaya, S.I. 1994: Autofault. A balanced cross section program for modelling thrust faults, $62 \mathrm{pp}$. + disc. Golden, Colorado, U.S.A.: Rockware, Inc.

Pedersen, S.A.S. 1979: Photogrammetric/geological mapping compared with field geological mapping of the area Freja Fjord, central Peary Land, North Greenland. Meddelelser Institute of Surveying and Photogrammetry 10, 174-181. Lyngby, Denmark: Technical University of Denmark.

Pedersen, S.A.S. 1981: The application of computer-assisted photogrammetric methods in the structural analysis of part of the North Greenland Fold Belt. Journal of Structural Geology 3, 253-264.

Pedersen, S.A.S. 1982: Structural analysis of the southern margin of the North Greenland Fold Belt in Peary Land, 230 pp. Unpublished Ph.D. thesis, University of Copenhagen, Denmark.

Pedersen, S.A.S. 1986a: A transverse, thin-skinned, thrust-fault belt in the Paleozoic North Greenland Fold Belt. Geological Society of America Bulletin 99, 1442-1455.

Pedersen, S.A.S. 1986b: Rubjerg Knude. Varv 1986-3, 84-98. København: Københavns Universitet.

Pedersen, S.A.S. 1987: Comparative studies of gravity tectonics in Quaternary sediments and sedimentary rocks related to fold belts. In: Jones, M.E. \& Preston, R.M.F. (eds): Defomation of sediments and sedimentary rocks. Geological Society Special Publication (London) 29, 165-180.

Pedersen, S.A.S. 1988: Glacitectonite: brecciated sediments and cataclastic sedimentary rocks formed subglacially. In: Goldthwait, R.P. \& Matsch, C.L. (eds): Genetic classification of glacigenic deposits, 89-91. Rotterdam: A.A. Balkema.

Pedersen, S.A.S. 1989: Jordartskort over Danmark, 1:200 000, Nordjylland, map 1. København: Danmarks Geologiske Undersøgelse (with English and German legend).

Pedersen, S.A.S. 1993: Glaciodynamic event and glaciodynamic sequence. In: Aber, J.S. (ed.): Glaciotectonics and mapping glacial deposits. Canadian Plains Proceedings 25(1), 67-85. Canadian Plains Research Center, University of Regina, Canada.

Pedersen, S.A.S. 1996: Progressive glaciotectonic deformation in Weichselian and Palaeogene deposits at Feggeklit, northem Denmark. Bulletin of the Geological Society of Denmark 42, 153-174.

Pedersen, S.A.S. 2000: Superimposed deformation in glaciotectonics. Bulletin of the Geological Society of Denmark 46, 125144.

Pedersen, S.A.S. \& Petersen, K.S. 1988: Sand-filled frost wedges in glaciotectonically deformed mo-clay on the island of Fur, Denmark. In: Croot, D.G. (ed.): Glaciotectonics: forms and processes, 185-190. Rotterdam: A.A. Balkema.

Pedersen, S.A.S. \& Petersen, K.S. 1995: West Scandinavian traverse; NW-Jutland. In: Schirmer, W. (ed.): Quaternary field trips in central Europe, 20-31. Pfeil, München: INQUA International Congress Berlin.

Pedersen, S.A.S. \& Petersen, K.S. 1997: Djurslands geologi, 96 
pp. København: Danmarks og Grønlands Geologiske Undersøgelse.

Pedersen, S.A.S., Petersen, K.S. \& Rasmussen, LA. 1988: Observations on glaciodynamic structures at the Main Stationary Line in western Jutland, Denmark. In: Croot, D.G. (ed.): Glaciotectonics: forms and processes, 177-183. Rotterdam: A.A. Balkema.

Petersen, K.S. 1978: Application of glaciotectonic analysis in geological mapping of Denmark. Danmarks Geologiske Undersøgelse Årbog 1977, 53-61.

Petersen, K.S. 2004: Late Quaternary environmental changes recorded in the Danish marine molluscan faunas. Geological Survey of Denmark and Greenland Bulletin 3, 268 pp.

Puggaard, C. 1851: Møens Geologie. Universitetets Guldmedaille Priisskrift, 287 pp. København: Reitzel.

Rasmussen, L.Aa. 1975: Kineto-stratigraphic glacial drift unit on Hindsholm, Denmark. Boreas 4, 209-217.

Rawson, P.F. et al. 2002: Stratigraphical procedure. Geological Society Professional Handbook, 57 pp. London: Geological Society.

Ricci Lucchi, F. 1986: The Oligocene to Recent foreland basins of Northern Apennines. International Association of Sedimentologists Special Publication 8, 105-139.

Richard, N. 1996: Sedimentological examination of the Late Weichselian sea-level history following deglaciation of northern Denmark. In: Andrews, J.T et al. (eds): Late Quaternary palaeoceanography of the North Atlantic margins. Geological Society Special Publication (London) 111, 261-273.

Rosenkrantz, A. 1944: Nye Bidrag til Forståelsen af Ristinge Klints Opbygning. Meddelelser fra Dansk Geologisk Forening 10, 431-435.

Sadolin, M., Pedersen, G.K. \& Pedersen, S.A.S. 1997: Lacustrine sedimentation and tectonics: an example from the Weichselian at Lønstrup Klint, Denmark. Boreas 26, 113-126.

Schirmer, T.W. 1988: Structural analysis using thrust-fault hanging-wall sequence diagrams: Ogden Duplex, Wasatch Range, Utah. American Association of Petroleum Geologists Bulletin 72, 573-585.

Schou, A. 1949: Atlas over Danmark 1. Landskabsfomerne. København: Det Kongelige Danske Geografiske Selskab.

Seidenkrantz, M.-S. \& Knudsen, K.L 1993: Middle Weichselian to Holocene palaeoecology in the eastern Kattegat, Scandinavia: foraminifera, ostracods and C14 measurements. Boreas 22, 299-310.

Sejrup, H.P., Aarseth, I., Ellingsen, K.L, Reither, E. \& Jansen, E. 1987: Quaternary stratigraphy of the Fladen area, central North Sea: a multidisciplinary study. Journal of Quatemary Science 2, 35-58.

Sejrup, H.P., Haflidason, H., Aarseth, I., King, E., Forsberg, C.F., Long, D. \& Rokoengen, K. 1994: Late Weichselian glaciation history of the northern North Sea. Boreas 23, 1-13.

Sejrup, H.P., Landvik, J.Y., Larsen, E., Janockos, J., Eiriksson, J. \& King, E. 1998: The Jæren area, a border zone of the Norwegian Channel Ice Stream. Quaternary Science Reviews 17, 801-812.

Sejrup, H.P., Larsen, E., Landvik, J.Y., King, E., Haflidason, H. \& Nesje, A. 2000: Quaternary glaciations in southern Fennos- candia: evidence from southwestern Norway and the northern North Sea region. Quaternary Science Reviews 19, 667685.

Sjørring, S. 1974: Klinterne ved Hundested. Dansk Geologisk Forening Årsskrift 1973, 108-117.

Sjørring, S. 1977: The glacial stratigraphy of the island of Als, southern Denmark. Zeitschrift für Geomorphologie. N.F. Supplement-Band 27, 1-11.

Sjørring, S. 1981: Weichselian till stratigraphy in the southern part of Denmark. Quaternary Studies in Poland 3, 103-109.

Sjørring, S. 1983: The glacial history of Denmark. In: Ehlers, J. (ed.): Glacial deposits in north-west Europe, 163-179. Rotterdam: A.A. Balkema.

Sjørring, S., Nielsen, P.E., Frederiksen, J., Hegner, J., Hyde, G., Jensen, J.B., Mogensen, A. \& Vortisch, W. 1982: Observationer fra Ristinge Klint, felt- og laboratorieundersøgelser. Dansk Geologisk Forening Årsskrift 1981, 135-149.

Slater, G. 1927: The disturbed glacial deposits in the neighborhood of Lönstrup, near Hjörring, north Denmark. Transactions Royal Society Edinburgh 55(2), 303-315.

Smed, P. 1995: Sten i det danske landskab, 181 pp. Brenderup, Denmark: Geografforlaget.

Stephan, H.-J. 1980: Glazialgeologische Untersuchungen im südlichen Geestgebiet Ditmarschens. Schriftenreihe des Naturwissenschaftlichen Vereins Schleswig-Holstein 50, 1-36.

Suppe, J. 1983: Geometry and kinematics of fault-bend folding. American Journal of Science 283, 684-721.

Suppe, J. 1985: Principles of structural geology, 537 pp. Englewood Cliffs, New Jersey: Prentice-Hall, Inc.

Tauber, H. 1966: Danske kulstof-14 dateringsresultater. Meddelelser fra Dansk Geologisk Forening 16, 153-176.

Ussing, N.V. 1903: Danmarks Geologi i almenfatteligt Omrids. Danmarks Geologiske Undersøgelse III. Række 2, 358 pp.

van der Meer, J.J.M. (ed.) 1987: Tills and glaciotectonics, 270 pp. Rotterdam: A.A. Balkema.

van der Wateren, D.F.M. 1985: A model of glacial tectonics, applied to the ice-pushed ridges in the central Netherlands. Bulletin of the Geological Society of Denmark 34, 55-74.

van der Wateren, D.F.M. 1992: Structural geology and sedimentology of push moraines, $230 \mathrm{pp}$. Unpublished thesis, University of Amsterdam, the Netherlands.

Vendsyssel nu og da 1981: Rubjerg Knude, 34 pp. Hjørring, Denmark: Vendsyssel Historiske Museum.

Weinberg, R.F. \& Schmeling, H. 1992: Polydiapirs: multiwavelength gravity structures. Joumal of Structural Geology 14, 425-436.

Wiltschko, D.V. 1979: A mechanical model for thrust sheet deformation at a ramp. Journal of Geophysical Research 84, 10911104.

Wiltschko, D.V. \& Dorr, J.A. 1983: Timing and deformation in overthrust belt and foreland of Idaho, Wyoming and Utah. American Association of Petroleum Geologists Bulletin 67, 1304-1322. 


\section{Appendix 1}

\section{Thrust-fault terminology}

Thrust fault: A surface along which an overlying block is displaced relative to an underlying block. Relative to bedding, two different elements are distinguished in a thrust fault: the ramp and the flat.

Ramp: A thrust-fault ramp cuts up-section in the direction of slip and dips towards the hinterland. The angle between bedding and the ramp is in general between $20^{\circ}$ and $30^{\circ}$ and will not exceed $45^{\circ}$ due to general rules of initial fracturing. A ramp is linked to a lower flat at the lower ramp hinge and to an upper flat atthe upper ramp hinge. A ramp may become foreland-dipping in special cases, mainly related to transport along an upper flat.

Flat: A thrust-fault flat is a bedding-parallel slip surface along which lateral displacement takes place. The lowermost thrust-fault zone in deformation complexes is in general referred to as the décollement surface, décollement zone or décollement level. In the present description the 'décollement level' is the term used for the thrust fault between a thrust sheet and an undisplaced footwall block below a footwall flat. As flats develop at different levels, the flats above the décollement level are referred to as intermediate flats and the upper flat (identical with the roof thrust fault). The thrust-fault flats are referred to by their depth from the upper reference zero-level indicated from the balanced section. Thus the $20 \mathrm{~m}$ flat level is the horizontal thrust faultsituated $20 \mathrm{~m}$ below the top reference level and 10 or $20 \mathrm{~m}$ above the décollement level.

Thrust sheet: A thrust sheet is the block displaced over a thrust fault. In this study, the thrust sheets are annotated according to the section in which they occur with two capital letters, referring to the named section, and a number referring to its position from leading edge to trailing end of the section. Thus, KR01 is the thrust sheet nearest to the foreland in the Kramrende section. A thrust fault is referred to according to the thrust sheet it displaces. A thrust sheet is synonymous with the hanging-wall block.

Hanging-wall block: The rock mass displaced over a thrust fault is a hanging-wall block. At the base, a hanging-wall flat and a hanging-wall ramp bound the hanging-wall block. At the roof, the hanging-wall block is capped by a top surface or a roof thrust fault. The roof thrust fault may constitute a footwall flat as well as a footwall ramp.

Footwall block: The rock below a thrust fault is a footwall block. The footwall block is bounded by a footwall ramp, and the top of the footwall block constitutes a top surface and/or a footwall flat.

Hanging-wall ramp: The segment of a ramp that bounds the hanging-wall block is a hanging-wall ramp. At the incipient displacement along a ramp, the hanging-wall ramp is thrust along a footwall ramp. When the hanging-wall ramp passes the upper ramp hinge, the hanging-wall ramp is thrust along a footwall flat. A hanging-wall anticline is always formed above a hanging-wall ramp.

Hanging-wall flat: The bedding-parallel thrust-fault boundary below the hanging-wall block is a hangingwall flat. When a hanging-wall flat is thrust up along a footwall ramp, the hanging-wall flat is re-orientated and becomes inclined towards the hinterland. When the hanging-wall flat is thrust along an upper footwall flat, the thrust fault again becomes bedding parallel. Footwall ramp: The inclined thrust-fault boundary of a footwall block is a footwall ramp. The footwall ramp is either the ramp boundary to the undisplaced foreland or it forms the trailing ramp boundary of a thrust sheet. In this study, the trailing footwall ramp is referred to using the annotation of the thrust sheet/ footwall block that underlies it. Thus the KR02 hanging-wall ramp is displaced up along the KR01 footwall ramp.

Footwall flat: A footwall flat is always the top of a footwall block. A footwall flat is more or less horizontal unless it is re-orientated during the displacement of a thrust sheet up along a ramp.

Hanging-wall anticline: When a hanging-wall block is thrust over an upper ramp hinge, the hanging-wall block is folded into an anticline with a foreland-dipping forelimb and a hinterland-dipping backlimb. This fold may also be termed a ramp anticline. During the progress of thrusting along the upper limb, the hanging-wall anticline develops into a flat-topped anticline. The flat-topped anticline may altematively be regarded as a flat-lying thrust sheet with a foreland-dipping forelimb or a frontal thrust-sheet nose. However, it is important to note that above a hanging-wall ramp thrust along a footwall flat, a foreland-dipping surface is formed. 
Footwall syncline: When a thrust fault propagates up along a ramp, an anticline-syncline pair is formed above, and in front of, the tip of the thrust fault, identical to the formation of a fault-propagation fold. When the thrust fault finally breaks through the folded layers, the fold pair is separated into a hanging-wall anticline and a footwall syncline. A footwall syncline therefore represents the gentle deformation below the footwall ramp; this deformation does not add significantly to the displacement along the thrust fault. The footwall syncline may also be regarded as a drag fold. The case where this is the only correct interpretation is along a growth fault. Here the sediments deposited syntectonically up against a hanging-wall ramp are successively bent into an overturned syncline. The footwall syncline is identical to a trailing syncline.

Duplex: A duplex is one or more thrust-sheet segments entirely bounded by thrust faults and thus overlain by a thrust sheet. A thrust sheet bounded by thrust faults is called a horse, originally regarded as a minor rootless thrust-sheet segment. Some of the lower thrustsheet segments described in this study are identical to horses, although the more neutral term 'segment' is adopted here. The fomation of a duplex is related to the 'footwall ramp collapse' (Boyer \& Elliott 1982), whereby progressive failure during thrust-fault propagation creates successively younger thrust faults below older ones. A parcel of thrust-sheet segments may be stacked to form a duplex complex.
Imbricate fan : A branching thrust-fault complex in which the individual thrust faults reach the surfaces or top level is called an imbricate fan. An imbricate fan is termed a duplex if the upper boundary is a roof thrust.

Antiformal stack: When a duplex is fault-bend-folded over a footwall ramp, an antiformal structure similar to a hanging-wall anticline is formed. Due to the complex stratigraphic relationship within such a structure, it is referred to as an antiformal stack.

Piggyback thrusting: When an older thrust sheet rests on the back of a younger thrust sheet and is transported due to the displacement along the thrust faults bounding the younger thrust sheets, it is called piggyback thrusting.

Piggyback basin: Just as piggyback thrusting refers to transport of a thrust sheet, the term is also applied to a basin that accumulates sediments during translation on the back of an active thrust sheet: the piggyback basin (Ori \& Friend 1984; Ricci Lucchi 1986). In this study, the term is mainly used in the description of an area of sedimentation between two thrust sheets. In general, the piggyback basin is deposited between a fault-bend thrust-sheet tip in the distal part of a thrust structure and bounded by a hanging-wall ramp at the proximal boundary of the basin. The term piggyback basin can only be applied to successions identified as having been deposited syntectonically. 


\section{Appendix 2}

\section{Specification of photogrammetric work}

The construction of the Rubjerg Knude cross-section (Plate 1) is based on a multi-model photogrammetric investigation of the cliff section, with the application of the method described by Dueholm (1992). A series of oblique photographs were taken from a Cessna fixed-wing aircraft in June 1993. The camera used for the photography was a Minolta XG2, which had been tested and calibrated for its optical specifications at the laboratory of photogrammetry at the Danish Technical University. The films used were standard $24 \times 36$ $\mathrm{mm}$ colour diapositive. The photographs were taken with $66 \%$ overlap from a distance of $200-300 \mathrm{~m}$ with an inclination angle of c. $35^{\circ}$. From the series of photographs, 70 samples were selected for setting up three sets of templates, which included 67 stereoscopic models.

In the laboratory, the orientation of the stereo-models was carried out based on ground control points adapted from two sets of vertical aerial photographs at a scale of 1:25 000, namely D9202 G 1365-66 and KMS 9203 A509-10 taken in May 1992. The strike of the section line is $\mathrm{N} 15^{\circ} \mathrm{E}$ from Rubjerg Knude and southwards. North of Rubjerg Knude, the strike is $N 24^{\circ} \mathrm{E}$, which is nearly parallel to the direction of the coastline along the beach. Fortunately, this is also a reasonable approximation of being perpendicular to the main concentration of structural strikes (bedding, thrust faults and fold axes; Fig. 10). A minor adjustment of the northem and southern section lines was subsequently implemented to make the cross-section fit to the general plane of orthographic projection with a projection axis striking $107^{\circ}$.

The stereoscopic instrument used for the investigation was a Kern DSR 15 analytical plotter with a DEC VMS operating system and the special attached GEOPROGRAM developed by Dueholm (1992). Five different labels were used for the features outlined by the floating mark: line type 1 includes bedding traces, line type 2 includes the main unconfomities, line type 3 was used for the contacts between geological units (members and formations), line type 4 outlines thrust faults, and finally line type 5 was used for topographic features (dunes, scree cones, strandplain, rockfalls etc.). Digitalisation of the geological structures in the stereo-models was administrated in data files, each covering a plot-area. The plot-areas covered $500 \mathrm{~m}$ of the Rubjerg Knude cross-section, and 13 plot-areas were used for the analogue plotting of data digitised in the stereo-model. The digital data were stored for the later construction of the cross-section and the transformation for other programs applied for the management of the cross-section display.

The orientation of models and setting up the system for the cross-section investigation took about one week, and the photo-geological compilation work was made over a period of three months in the autumn of 1993. The average progress was two models per day. The benefit of the multi-model analytical stereo-plotter is that features can be traced continuously from one model to the adjacent models. Thus one is not restricted to working model by model, but the compilation can be extended over several models using the same set of templates. By January 1994, the cross-section could be plotted out in a normal vertical projection profile plan from the stored digital data with the application of the program facilities prepared by Dueholm (1992). The scale of the Rubjerg Knude crosssection in the draft versions is 1:500, and the accuracy of the plotted data is estimated to be better than 25 $\mathrm{cm}$.

In 1995-1996, the cross-section details observed in the photo-geological models were checked in the field, and in 1997 the templates were set up again for correction, adjusting and compilation of details in the cross-section. 